\title{
Novel Aspects on the Preparation of Spirocyclic and Fused Unusual $\beta$-Lactams
}

\author{
Benito Alcaide*A AND Pedro Almendros*B
}

ADepartamento de Química Orgánica I, Facultad de Química, Universidad Complutense de Madrid, 28040-Madrid. Spain

BInstituto de Química Orgánica General, CSIC, Juan de la Cierva 3, 28006Madrid, Spain

E-mail: alcaideb@quim.ucm.es; iqoa392@iqog.csic.es

1 Introduction

2 Preparation of Spirocyclic- $\beta$-Lactams with Non-Classical Structure

2.1 Using Cycloaddition Reactions

2.2 Using Cyclization and Rearrangement Reactions

2.3 Using Metal-Mediated Reactions

3 Preparation of Fused $\beta$-Lactams with Non-Classical Structure

3.1 Using Cycloaddition Reactions

3.2 Using Radical Reactions

3.3 Using Metal-Mediated Reactions

3.4 Using Cyclization Reactions

4 Conclusions

\begin{abstract}
Lactam antibiotics have occupied a central role in the fight against pathogenic bacteria and the subsequent rise in quality of life for the world population as a whole. However, the extensive use of common $\beta$-lactam antibiotics such as penicillins and cephalosporins in medicine has resulted in an increasing number of resistant strains of bacteria through mutation and $\beta$ lactamase gene transfer. The resistance of bacteria to the classical $\beta$-lactam antibiotics can be overcome, e.g., by using novel $\beta$-lactam moieties in drugs which show much higher stability towards these resistance bacteria. In addition, there are many important nonantibiotic uses of 2azetidinones in fields ranging from enzyme inhibition to gene activation. These biological activities, combined with the use of these products as starting materials to prepare $\alpha$ - and $\beta$-amino acids, alkaloids, heterocycles, taxoids, and other types of compounds of biological and medicinal interest, provide the motivation to explore new methodologies for the synthesis of substances based on the $\beta$-lactam core. The aim of this chapter is to provide a survey of the types of reactions used to prepare non-conventional spirocyclic and fused $\beta$-lactams, concentrating on the advances that have been made in the last decade, and in particular in the last five years. We will draw special attention to radical cyclizations, cycloaddition reactions, and transition metal-catalyzed reactions.
\end{abstract}


Keywords Cycloadditions - Fused-rings - $\beta$-Lactams - Metals - Spirocycles

\section{1}

\section{Introduction}

Since the advent of penicillin, the $\beta$-lactam antibiotics have been the subject of much discussion and investigation, within both the scientific and public sectors [1]. $\beta$-Lactam antibiotics have occupied a central role in the fight against pathogenic bacteria and the subsequent rise in quality of life for the world population as a whole. However, the extensive use of common $\beta$-lactam antibiotics such as penicillins and cephalosporins (Fig. 1) in medicine has resulted in an increasing number of resistant strains of bacteria through mutation and $\beta$ lactamase gene transfer. It is well known that bacterial resistance to $\beta$-lactam antibiotics stems from the expression of a $\beta$-lactamase that catalyzes the hydrolytic cleavage of the substrate amide bond. $\beta$-Lactamases can be classified into four different classes (A-D) according to structure. Class $A, C$, and D $\beta$ lactamases are serine enzymes, the serine residue acting as the nucleophile in the hydrolysis reaction. Class A $\beta$-lactamases are also known as "penicillinases" on account of the ease with which they can hydrolyse penicillins, and class $C \beta$ lactamases as "cephalosporinases" by virtue of their increased activity against cephalosporins. Of the four structural classes of this enzyme, metallo- $\beta$ lactamases (class B) contain zinc and other divalent cations as cofactors.<smiles>[R]C(=O)N[C@H]1C(=O)N2[C@H]1S[C@](C)(C(=O)O)[C@H]2C(=O)O</smiles>

penicillins<smiles>[R]C(=O)N[C@@H]1C(=O)N2C(C(=O)O)=C(COC(C)=O)CS[C@H]12</smiles>

cephalosporins

Figure 1

Two main therapeutic strategies have been adopted to counteract bacterial resistance to $\beta$-lactam antibiotics. One strategy consists of modifying the structure of the $\beta$-lactam antibiotic, aiming to render it insensitive to the $\beta$-lactamase attack. Recently, trinems antibiotics (depicted in Fig. 2) have been the subject of considerable study owing to their broad spectrum of antibacterial activity, resistance to $\beta$-lactamases and stability to renal dehydropeptidases [2]. As a result of their impressive biological activity, tricyclic $\beta$-lactams have become interesting targets for synthesis. A second approach uses a reagent, typically a $\beta$-lactam derivative, which incapacitates the $\beta$-lactamase, in synergy with the $\beta$-lactam antibiotic. Clavulanic acid (depicted in Fig. 2) is the archetipe of $\beta$-lactamase 
inhibitors [3]: in synergistic mixture with amoxicillin (depicted in Fig. 2), under the name "augmentin", it arrived to the practice some years ago. Both approaches have produced results and a new generation of antibiotics has been developed.

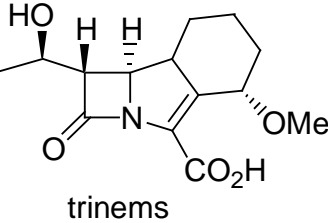<smiles>CC1(C)S[C@@H]2[C@H](NC(=O)[C@@H](N)c3ccc(O)cc3)C(=O)N2[C@H]1C(=O)O</smiles>

amoxicillin<smiles>O=C(O)[C@H]1/C(=C/CO)O[C@@H]2CC(=O)N21</smiles>

clavulanic acid

In addition, there are many important nonantibiotic uses of 2-azetidinones in fields ranging from enzyme inhibition [4] to gene activation [5]. Systems containing one carbon atom common to two rings, spirocyclic compounds, represent an important structural organization. Spirocyclic $\beta$-lactams (Fig. 3) behave as $\beta$-turn mimetics [6], as well as enzyme inhibitors [7], they are precursors of $\alpha, \alpha$-disubstituted $\beta$-amino acids [8], and the spiranic $\beta$-lactam moiety is present in chartellines and chartelamides [9], a family of marine natural products. Synthetic studies and biosynthetic speculation inspired by an unexpected reaction on the marine alkaloid chartelline $C$ have been described [9f].<smiles>[R]C1N(N([R1])C(=O)NC)C(=O)C12CCCN2CC</smiles>

$\beta$-turn mimetics<smiles>[R]c1ccc(C2N(c3ccc([R])cc3)C(=O)C23CCC([R])(c2ccc(Cl)cc2)CC3)cc1</smiles>

inhibitors of cholesterol absortion $\mathrm{R}^{1}=\mathrm{OH}, \mathrm{R}^{2}=\mathrm{F}, \mathrm{R}^{3}=\mathrm{OH}($ Sch 58053) $\mathrm{R}^{1}=\mathrm{OMe}, \mathrm{R}^{2}=\mathrm{H}, \mathrm{R}^{3}=\mathrm{H}(\mathrm{Sch} 54016)$

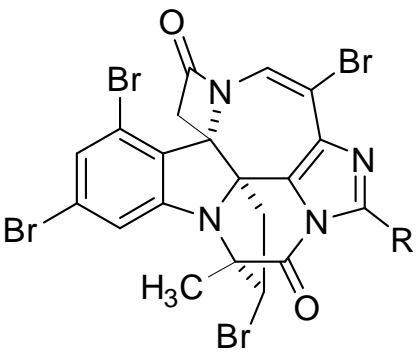

$\mathrm{R}=\mathrm{H}$ (chartelamide $\mathrm{A})$

$\mathrm{R}=\mathrm{Br}$ (chartelamide $\mathrm{B})$

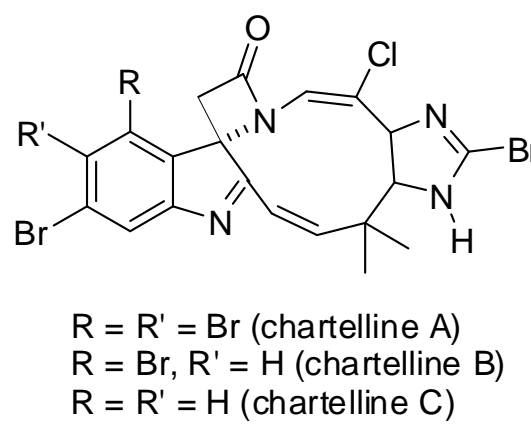

Figure 3

These biological activities, combined with the use of these products as starting materials to prepare $\alpha$ - and $\beta$-amino acids, alkaloids, heterocycles, taxoids, and other types of compounds of biological and medicinal interest [10], 
provide the motivation to explore new methodologies for the synthesis of substances based on the $\beta$-lactam core.

The cyclic 2-azetidinone skeleton has been extensively used as a template on which to build the carbo(hetero)cyclic structure joined to the four-membered ring, using the chirality and functionalization of the $\beta$-lactam ring as a stereocontrolling element. This review embraces the gamut of unusual $\beta$-lactams, including spiranic and fused 2-azetidinones. Without a doubt this contribution does not include every report of unusual $\beta$-lactams, nor does it fully summarize all aspects of the cited references. Instead, examples have been chosen based on their demonstrated and potential usefulness, in the opinion of the authors. The aim of this review is to provide practicing and aspirant $\beta$-lactam chemists with a survey and flavor of the types of reactions used to prepare non-conventional $\beta$-lactams, and insight into why certain methodologies are advantageous under particular circumstances, concentrating on the advances that have been made in the last decade, and in particular in the last five years. We will draw special attention to radical cyclizations, cycloaddition reactions, and transition metal-catalyzed reactions.

\section{2}

\section{Preparation of Spirocyclic- $\beta$-lactams with Non-Classical Structure}

\section{1}

\section{Using Cycloaddition Reactions}

It has been reported the synthesis of pyrrolidine and tetrahydrofuran spiro- $\beta$ lactams by a Staudinger-type process [11]. The $\beta$-lactams $\mathbf{4}$ and $\mathbf{5}$ were prepared by reaction of either 2-tetrahydrofuroyl chloride $\mathbf{2}$ or 3-tetrahydrofuroyl chloride $\mathbf{3}$ with imines 1 (Scheme 1). The acid chloride was added to a stirred, refluxing solution of the imine and triethylamine in toluene. After refluxing of the solution overnight and aqueous work-up, a mixture of cis- and trans-spiro- $\beta$-lactams $\mathbf{4}$ or $\mathbf{5}$ was obtained in good to moderate yields. When other solvents such as dichloromethane and lower temperatures were used, the starting materials were always recovered. The $\beta$-lactams $\mathbf{4}$ and 5 are the expected products of the [2+2] cycloaddition reaction of imines with the corresponding cyclic ketenes. In all cases, the diastereomeric mixtures of spiro- $\beta$-lactams $\mathbf{4}$ and $\mathbf{5}$ were separated by 
column chromatography. The relative configuration in the stereogenic centres of the azetidinone ring was established by nuclear overhauser effect (NOE) difference NMR experiments.

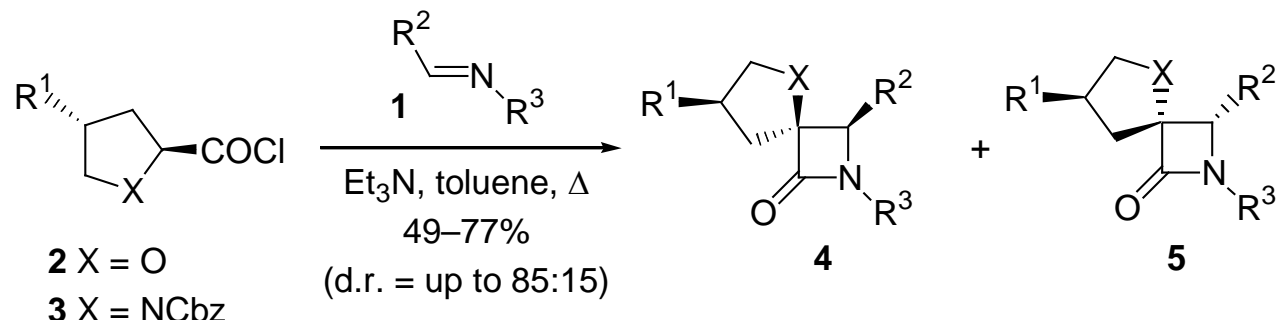

\section{Scheme 1}

This protocol was also apply to diazepam derivatives 6 [12]. When these compounds were treated with $N$-benzyloxycarbonyl-L-proline acid chloride and tetrahydrofuroyl chloride, the expected spirocyclic systems 7 (Scheme 2) were obtained in good yields. In the case of the $N$ - benzyloxycarbonyl-t-proline acid chloride, the reaction was carried out at room temperature, while the process involving the tetrahydrofuroyl chloride needed to be performed in refluxing toluene. This higher temperature was the likely cause of the loss of selectivity observed in the latter case, in which a 10:1 mixture of diastereoisomers was obtained.

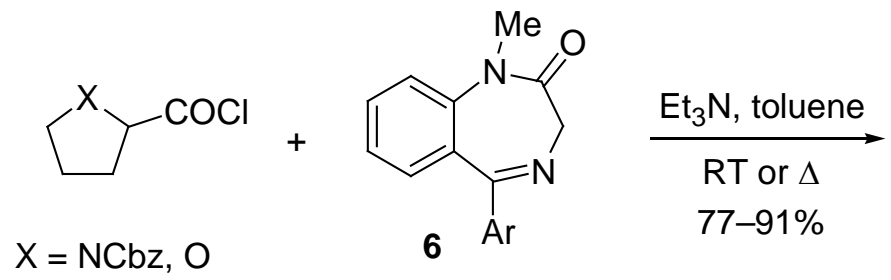

Staudinger reaction of imine $\mathbf{8}$ derived from 7-oxanorbornenone with 2alkoxyacetyl chlorides in the presence of $\mathrm{Et}_{3} \mathrm{~N}$ (toluene, RT), afforded $\beta$-lactams 9 (Scheme 3). These were obtained as single diastereomers, and no traces of the corresponding isomeric exo- $\beta$-lactams were detected in the crude reaction products [13]. It is worth mentioning that this stereochemical outcome of $\beta$-lactam formation with acid chlorides under Staudinger reaction conditions was opposite to the one expected from a simple [2+2]-cycloaddition reaction, which should have taken place from the exo face of compound $\mathbf{8}$. 
<smiles>C=CCN=C1CC2C=CC1O2</smiles>

8

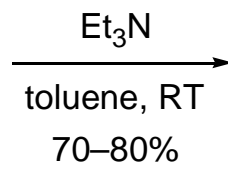

70-80\%

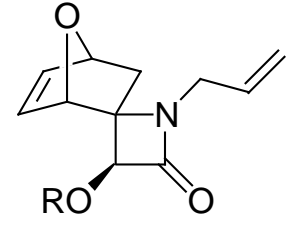

9

Scheme 3

Optically active $\alpha$-methylene- $\beta$-lactam 10 was synthesized and submitted to 1,3-dipolar cycloadditions with diazomethane, 4-methoxybenzonitrile oxide, and diphenylnitrone [14]. All cycloadditions proceed with complete regioselectivity giving products 11-13 in an anti-fashion with respect to the substituent at the $\mathrm{C} 4$-position of the starting $\beta$-lactam in diastereomeric ratios of about 85:15 (Scheme 4). Pure optically active compounds could be obtained in almost all cases after chromatography. Unambiguous structure elucidation could be achieved by X-ray crystal analysis and NOE investigations.

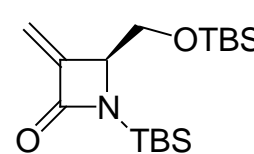

10

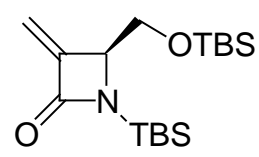

10<smiles>C=C1C(=O)N([10SH2])[C@@H]1C[OH+][SbH2]</smiles>

10

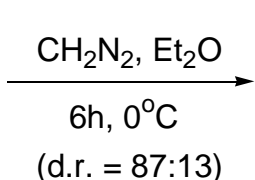

(d.r. $=87: 13)$

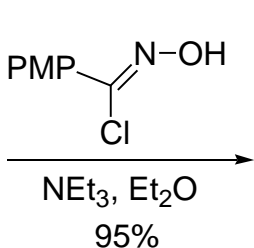

(d.r. $=87: 13)$

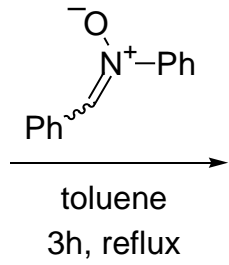

(d.r. $=86: 14)$

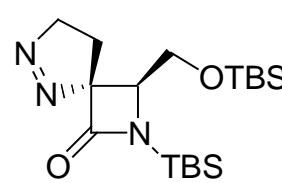

$11 a$<smiles>[R5]C1=NO[C@]2(C1)C(=O)N(C(C)(C)C)[C@@H]2C[OH2+]</smiles>

$12 a$<smiles></smiles>

$13 a$<smiles>[13CH3]N1C(=O)[C@@]2(CCN=N2)[C@@H]1CO[SbH3]</smiles>

$11 b$

Scheme 4

\section{2}

\section{Using Cyclization and Rearrangement Reactions}

A model compound $\mathbf{1 5}$ containing an indole $\beta$-lactam moiety in chartellines was synthesized from the Mannich reaction of isatin imine with ketene silyl acetal, followed by $\beta$-lactam formation through cyclization of the resulting $\beta$-amino acid 
14 (Scheme 5) [15]. L-Proline-catalyzed direct asymmetric Mannich reactions of $N$-PMP protected $\alpha$-imino ethyl glyoxylate with various $\alpha, \alpha$-disubstituted aldehydes affords quaternary $\beta$-formyl $\alpha$-amino acid derivatives with excellent yields and enantioselectivities. The Mannich products are further converted to the corresponding spiranic $\beta$-lactams [16].<smiles>CN1C(=O)C(N)(CC(=O)O)c2ccccc21</smiles>

14

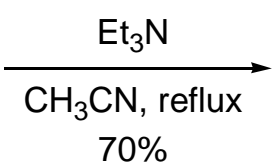

$70 \%$<smiles>CN1C(=O)C2(CC(=O)N2)c2ccccc21</smiles>

15

Scheme 5

The synthesis of spiro-linked $\beta$-lactam-dihydropyridines $\mathbf{1 7}$ through the cyclization of lithiated pyridine carboxamides $\mathbf{1 6}$ has been achieved (Scheme 6) [17]. Thus, treatment of 16 with LDA at $-40{ }^{\circ} \mathrm{C}$ and addition of methyl chloroformate led to the formation of the corresponding dearomatized product in 91\% yield. Other acylating agents, namely, benzyl chloroformate and benzoyl chloride, were equally effective at promoting this new type of cyclization as was methyl triflate. Methyl iodide gave significantly lower yields, and no dearomatized product was obtained on quenching with ammonium chloride, a good indication that electrophilic attack at the pyridine nitrogen is needed to promote the cyclization. It is presumed that the electrophile attacks the lithiated amide at the pyridine nitrogen rather than the considerably more basic organolithium center, presumably for steric reasons. The resulting pyridinium system is activated toward attack at $\mathrm{C} 4$, and the spirocyclic $\beta$-lactam results.<smiles>[X]c1cc(C(=O)N(Cc2ccccc2)Cc2ccccc2)cc([X])n1</smiles>

16

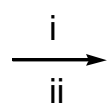

$17(39-91 \%)$

Scheme 6 i) LDA, $-40{ }^{\circ} \mathrm{C}$; ii) E-Cl.

1,3-Dipolar cycloaddition of nitrones 18 to bicyclopropylidene 19 gave the corresponding cycloadducts 20. Treatment of these bis-spirocyclopropanated isoxazolidines with trifluoroacetic acid in acetonitrile furnished the corresponding 3-spirocyclopropanated $\beta$-lactams $\mathbf{2 1}$ in good yields. The structure of the $\beta$-lactam derived from $N$-benzyl- $C$-(methoxycarbonyl)nitrone was proved by X-ray crystal structure analysis. Thus, this new method furnishes compounds with a 5azaspiro[2.3]hexan-4-one skeleton in 68-94\% overall yield in two simple steps 
(Scheme 7) [18]. The one-pot three-component reaction for the direct conversion of certain alkylhydroxylamine hydrochlorides (alkyl = benzyl, $p$-methoxybenzyl, benzhydryl, tert-butyl), formaldehyde or an alkyl glyoxylate and bicyclopropylidene 19 to furnish the 3-spirocyclopropanated 2-azetidinones related to $\mathbf{2 1}$ has also been developed. Microwave heating of mixtures of the three components in the presence of sodium acetate in ethanol for 15-120 min furnished the spirocyclic $\beta$-lactams in 49-78\% yield (7 examples) [19].

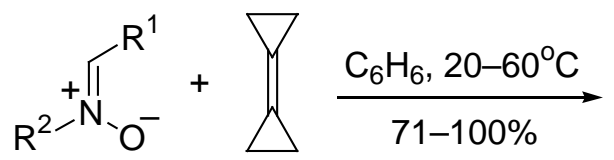

18<smiles>[R]C1N([R])OC2(CC2)C12CC2</smiles>

20

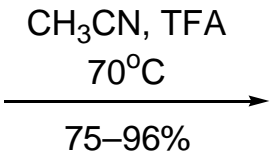
$\mathrm{R}^{2}$

21

$\mathrm{R}^{1}=\mathrm{CO}_{2} \mathrm{Me}, \mathrm{Ph}, \mathrm{CN}, 2-\mathrm{Py} ; \mathrm{R}^{2}=\mathrm{Bn}, \mathrm{PMB}, \mathrm{Me}$

\section{Scheme 7}

Oxaciclopropane formation has been observed to give the highly strained oxiranyl- $\beta$-lactam 23, possessing a spirocyclic structure by treatment of a 3[bromo(nitro)methyl] 3-hydroxy- $\beta$-lactam 22 with bases (Scheme 8) [20]. The structure of the spirocycle $\mathbf{2 3}$ was proved by X-ray crystal structure analysis.<smiles>CC1(C)OC[C@H]([C@H]2N([Y10]#P)C(=O)[C@]2(O)C(Br)[N+](=O)[O-])O1</smiles>

22

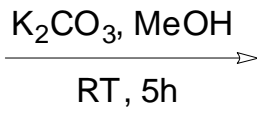<smiles>[Y6]N1C(=O)[C@@]2([C@@H]3COC(C)(C)O3)[C@H]([N+](=O)[O-])[C@H]12</smiles>

$23(60 \%)$

Scheme 8

Treatment of bicyclic lactone $\mathbf{2 4}$ with benzylamine in dioxane afforded an open chain triflate amide, which was stirred in THF in the presence of potassium carbonate to cyclizate to the spirocyclic $\beta$-lactam 25 (Scheme 9) [21].<smiles>CC1(C)O[C@H]2[C@@H](CN)OC(=O)[C@@]2(C)O1</smiles>

24

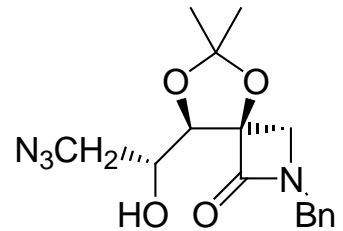

$25(89 \%)$

Scheme 9 i) $\mathrm{BnNH}_{2}$, 1,4-dioxane, RT; ii) $\mathrm{K}_{2} \mathrm{CO}_{3}$, THF, RT, 8 days. 


\section{3}

\section{Using Metal-Mediated Reactions}

The synthesis of oxaspiro- $\beta$-lactam structures containing five- and six-membered rings was explored through RCM reaction. Unfortunately, dienes 26-29 having a quaternary center proved to be resistant to ring closure mediated by Ru-based first generation Grubbs' carbene under smooth reaction conditions (5 mol\%, $\mathrm{CH}_{2} \mathrm{Cl}_{2}$, $25{ }^{\circ} \mathrm{C}$ ). The majority of the reaction mixture was composed of unreacted dienes. It was found that dienic substrates 26-29 require more vigorous conditions for ring closure. Spiro ring-closing metathesis was achieved upon heating at reflux temperature in a toluene solution. Under optimized conditions (5 mol\% Grubbs' carbene, toluene $0.03 \mathrm{M}, 110{ }^{\circ} \mathrm{C}$ ), good yields of unusual $\beta$-lactams 30-32 containing dihydrofuran, dyhydropyran and dyhydropyranone spiranic rings were obtained (Scheme 10). The six-membered spiro compound 33 which bears an exocyclic methylene was achieved when the spirocyclization taked place on triene 29. No traces of the five-membered regioisomer $\mathbf{3 4}$ could be detected, because only the least substituted double bond of the 1,3-diene system reacted (Scheme 10) [22].

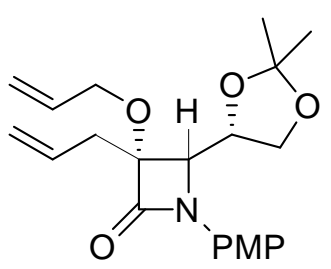

26<smiles>[R16]N1C(=O)[C@](CC=C)(O/C=C/C(OC)OC)[C@@H]1[C@H]1COC(C)(C)O1</smiles>

27<smiles>[R16]N1C(=O)[C@@](C=C)(OC(=O)C=C)[C@@H]1[C@H]1COC(C)(C)O1</smiles>

28

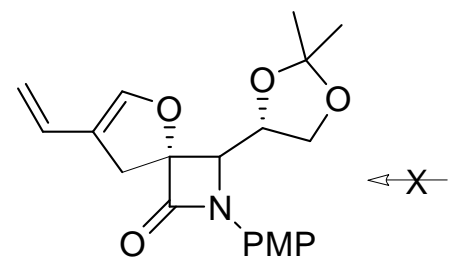

34
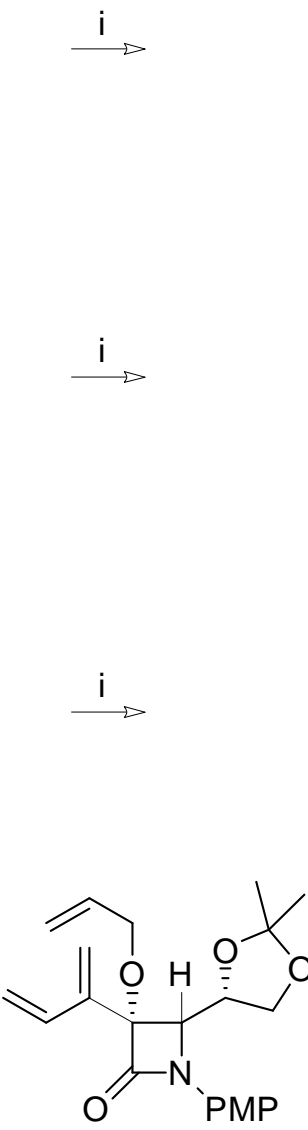

29<smiles>CC1(C)OC[C@H]([C@@H]2N(PNP)C(=O)[C@@]23CC=CCO3)O1</smiles>

30 (91\%)

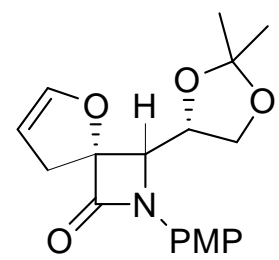

31 (60\%)<smiles>CC1(C)OC[C@H](C2N(P)C(=O)[C@@]23CC=CC(=O)O3)O1</smiles>

32 (100\%)

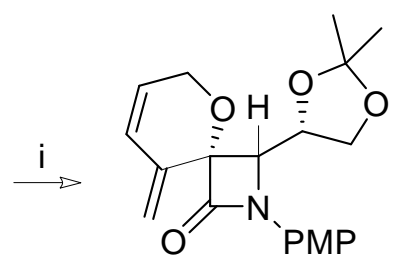

$33(53 \%)$ 
Scheme 10 i) $\left[\mathrm{Cl}_{2}\left(\mathrm{PCy}_{3}\right)_{2} \mathrm{Ru}=\mathrm{CHPh}\right]$, toluene, reflux.

Treatment of enynes 35 and 36 with first generation Grubbs' carbene under the above diene ring-closing metathesis conditions, did not furnished the desired spirocycles. Next trials of cyclization were attempted by using its imidazolidinylidene analogue, the more active second generation Grubbs' carbene. In this way, the spirocyclization was effective on enyne- $\beta$-lactams $\mathbf{3 5}$ and 36 to afford the inner-outer-ring dienes (cyclic dienes in which one of the double bonds is endo-cyclic) 37 and 38 (Scheme 11) [23].

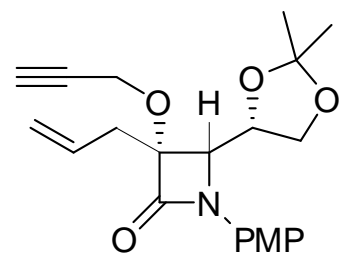

35

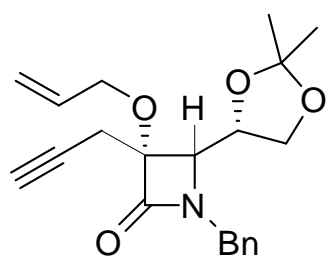

36<smiles>[Y16]N1C(=O)[C@@]2(CC=C(C=C)CO2)C1(C1COC(C)(C)O1)[C@H]1COC(C)(C)C1</smiles>

37 (35\%)<smiles>C=CC1=CCO[C@]2(C1)C(=O)N(Cc1ccccc1)C2[C@H]1COC(C)(C)O1</smiles>

38 (44\%)

Scheme 11 i) $\left[\mathrm{Cl}_{2}(\mathrm{Im})\left(\mathrm{Cy}_{3} \mathrm{P}\right) \mathrm{Ru}=\mathrm{CHPh}\right]$, toluene, reflux.

Palladium-catalyzed reaction of bromo dienes 39 was complete after a few hours, and afforded spirocycles $40 \mathrm{a}$ and $\mathbf{4 0 b}$ as single regio- and stereoisomers (Scheme 12). The Heck spirocyclization reaction is regioselective, giving fivemembered heterocycles. In addition, it is stereoselective because the Heck adducts were obtained as single geometric isomers [23].

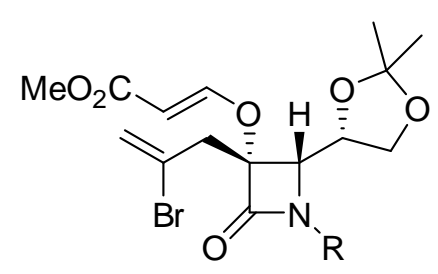

$39 a \mathrm{R}=\mathrm{PMP}$

$39 \mathrm{~b} R=\mathrm{Bn}$

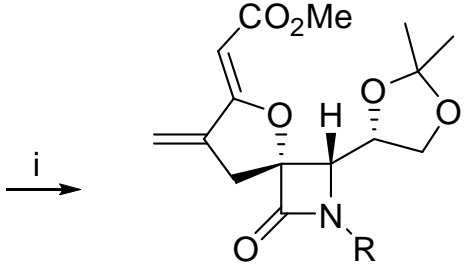

40a $\mathrm{R}=\mathrm{PMP}(47 \%)$

40b $\mathrm{R}=\mathrm{Bn}(50 \%)$

Scheme 12 ii) $\mathrm{Pd}(\mathrm{OAc})_{2}, \mathrm{PPh}_{3}, \mathrm{~K}_{2} \mathrm{CO}_{3}, \mathrm{DMF}, 105^{\circ} \mathrm{C}$.

The $\mathrm{AgNO}_{3}$-induced reaction of $\beta$-lactam-tethered $\alpha$-allenic alcohols $\mathbf{4 1}$ gave, with concomitant acetonide cleavage, the spirocyclic dihydrofurans 42 in quantitative yields (Scheme 13) [22]. 
<smiles>[R]C(=C)C1(O)C(=O)N([R1])[C@H]1[C@H]1COC(C)(C)O1</smiles>

41a $R^{1}=P M P, R^{2}=M e$

41b $R^{1}=P M P, R^{2}=P h$

41c $R^{1}=B n, R^{2}=M e$

41d $R^{1}=B n, R^{2}=P h$
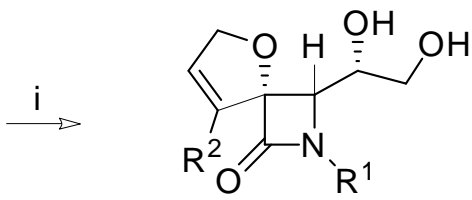

$42 \mathrm{a}(100 \%)$

42b (100\%)

42c $(100 \%)$

42d (100\%)

Scheme 13 ii) $\mathrm{AgNO}_{3}$ (1 equiv), acetone- $\mathrm{H}_{2} \mathrm{O}$ (1:1), reflux.

The palladium-catalyzed cyclizative coupling reaction of $\alpha$-allenols $\mathbf{4 1}$ with alkenyl halides was also explored. The transformation of allenols $\mathbf{4 1}$ into spirocyclic disubstituted dihydrofuran $\beta$-lactams $\mathbf{4 3}$ was readily achieved in high yields, by treatment with allyl bromide or 2,3-dibromopropene in the presence of palladium(II) chloride (5 mol\%) (Scheme 14) [23].

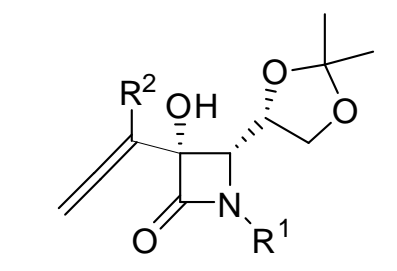

41a $R^{1}=P M P, R^{2}=M e$

41b $R^{1}=P M P, R^{2}=P h$

41c $R^{1}=B n, R^{2}=M e$

41d $R^{1}=B n, R^{2}=P h$

41d $R^{1}=B n, R^{2}=P h$
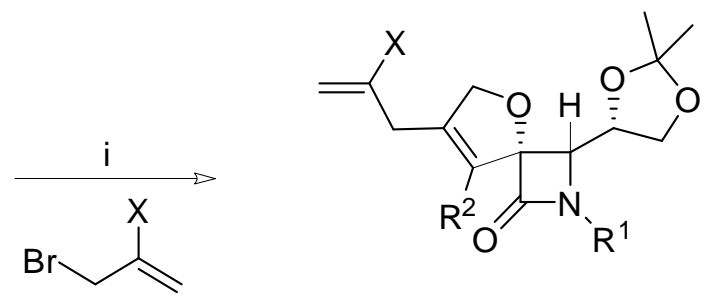

$$
\begin{aligned}
& \text { 43a } X=H(85 \%) \\
& \text { 43b } X=H(100 \%) \\
& \text { 43c } X=H(65 \%) \\
& \text { 43d } X=H(93 \%)
\end{aligned}
$$$$
\text { 43e } X=\operatorname{Br}(95 \%)
$$

Scheme 14 i) 5 mol \% $\mathrm{PdCl}_{2}$, DMF, RT.

The formation of spirocyclic azetidinones $\mathbf{4 3}$ could be explained following a Pd(II)-catalyzed mechanism. Initial Pd(II)-coordination gave an allenepalladium complex 44. Species $\mathbf{4 4}$ suffers an intramolecular cycloetherification reaction to give the palladadihydrofuran $\mathbf{4 5}$. Intermediate $\mathbf{4 5}$ reacted with the appropriate allyl bromide to form intermediates $\mathbf{4 6}$, which after dehalopalladation generated spiro$\beta$-lactams 43 with concomitant regeneration of the Pd(II) species (Scheme 15) [23]. 
<smiles>[X]C(=C)CC1=C([R])C2(OC1)C(=O)N([R1])C2C1COC(C)(C)O1</smiles>

43

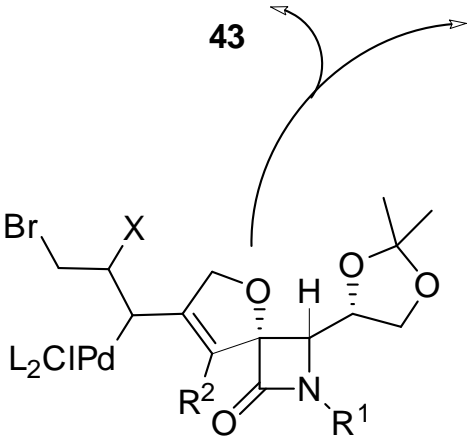

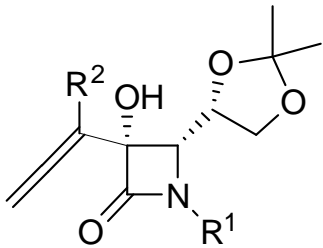

41

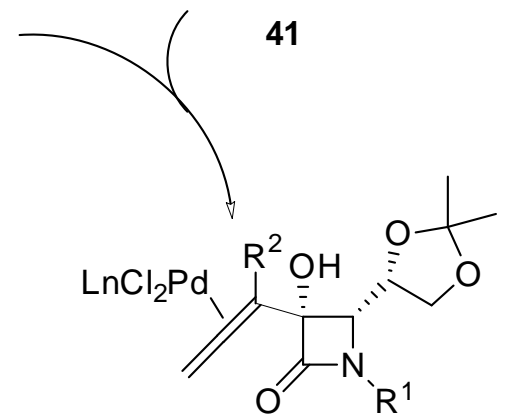

46

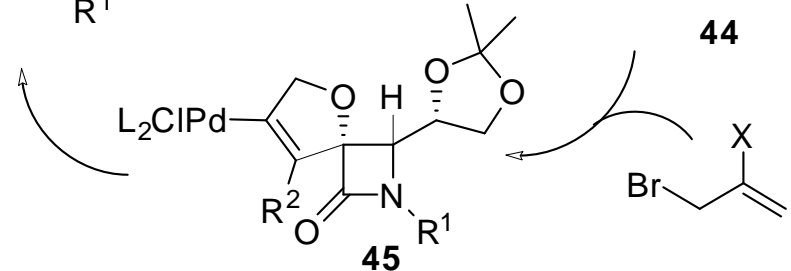

Scheme 15

Using a single catalytic system it has been successfully accomplished a domino cyclization of $\alpha$-allenols-cross coupling (Heck, Sonogashira, and Suzuki) reaction sequence for the synthesis of spiro- $\beta$-lactams [24]. Treatment of enantiopure $\alpha$-allenols $\mathbf{4 1}$ with the appropriate coupling partner under optimized conditions, led to formation of the desired products $47-49$ as single isomers (Scheme 16). Similarly, the heterocyclizative cross-coupling between 2azetidinone-tethered allenols and $\alpha$-allenic acetates has resulted in the achievement of $\beta$-lactam-dihydrofuran hybrids in good yields [25]. 
<smiles>CO[C@]1(C)C(=O)N([Pb])[C@@H]1[C@H]1COC(C)(C)O1</smiles>

$41 a$

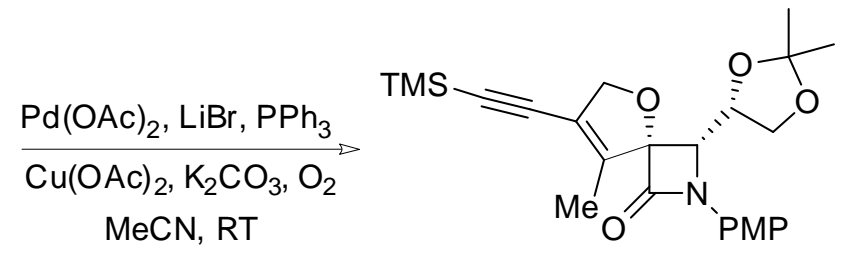

47 (43\%)<smiles>C=C(C)[C@]1(O)C(=O)N(Cc2ccccc2)[C@H]1[C@H]1COC(C)(C)O1</smiles>

41c
$\frac{\mathrm{Pd}(\mathrm{OAc})_{2}, \mathrm{LiBr}, \mathrm{PPh}_{3}}{\mathrm{Cu}(\mathrm{OAc})_{2}, \mathrm{~K}_{2} \mathrm{CO}_{3}, \mathrm{O}_{2}}$ MeCN, RT<smiles>CC1=C(c2ccc(C)cc2)CO[C@]12C(=O)N(Cc1ccccc1)[C@H]2[C@H]1COC(C)(C)O1</smiles>

48 (47\%)<smiles>[R]C(=C)C1(O)C(=O)N(Cc2ccccc2)[C@H]1[C@H]1COC(C)(C)O1</smiles>

41c

41d

$\pi \mathrm{CO}_{2} \mathrm{Me} \frac{\mathrm{Pd}(\mathrm{OAc})_{2}, \mathrm{LiBr}, \mathrm{PPh}_{3}}{\mathrm{Cu}(\mathrm{OAc})_{2}, \mathrm{~K}_{2} \mathrm{CO}_{3}, \mathrm{O}_{2}}$ MeCN, RT<smiles>[R]C1=C(/C=C/C(OC)OC)CO[C@]12C(=O)N(Cc1ccccc1)[C@H]2[C@H]1COC(C)(C)O1</smiles>

$49 \mathrm{a} R=\mathrm{Me}(58 \%)$

49b R = Ph (56\%)

Scheme 16

The formation of spirolactams $\mathbf{4 7 - 4 9}$ could be rationalized in terms of a sequence domino cyclization of $\alpha$-allenols-cross coupling reactions. A palladium(II)-catalyzed mechanism for the domino sequence leading to spiranic adducts 47-49 is proposed in Scheme 17. It could be presumed that the initially formed allenepalladium complex $\mathbf{5 0}$ undergoes an intramolecular attack by the hydroxyl group (oxypalladation), giving rise to the spirocyclic vinylic palladium species 51. Next, palladadihydrofuran intermediate $\mathbf{5 1}$ is trapped by the crosscoupling reagents leading to compounds 47-49. For example, the palladium species $\mathbf{5 1}$ can then form the intermediate $\mathbf{5 2}$ in a subsequent Heck reaction with acrylate, which leads to the final spirocycles 49a and 49b and $\operatorname{Pd}(0)$ in a $\beta$-hydride elimination [24]. It is necessary for the catalytic cycle that $\operatorname{Pd}(0)$ is reoxidized to $\mathrm{Pd}(\mathrm{II})$; this is achieved by the addition of $\mathrm{Cu}(\mathrm{OAc})_{2}$, which does not interfere with the course of the reaction. 


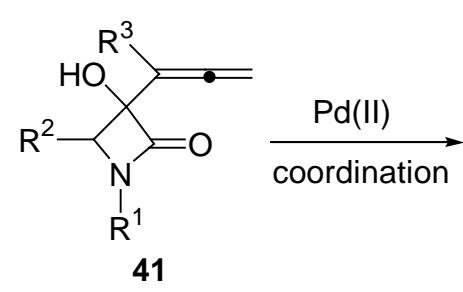

41

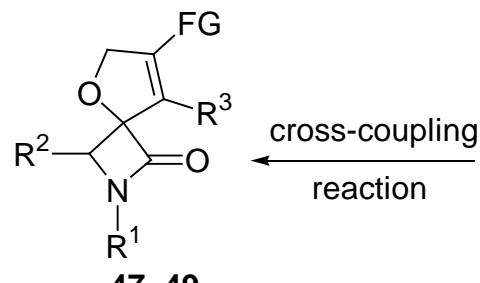

47-49

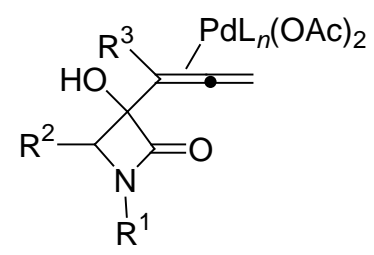

50<smiles>[R]C1=C(/C=C/C(C)=O)COC12C(=O)N([R])C2[R]</smiles>

$49 a, 49 b$

$\begin{aligned} & \beta \text {-hydride } \uparrow \\ & \text { elimination }\end{aligned}-\mathrm{HPdL}_{n}(\mathrm{OAc})$

oxypalladation<smiles>[R19]C1=C([R])C2(OC1)C(=O)N([R])C2[R]</smiles>

51<smiles>[R]C1=C(CC([R]C(=O)O)C(=O)OC)COC12C(=O)N([R])C2[R]</smiles>

52

$n=0,1 ; \mathrm{FG}=$ aryl, heteroaryl, alkenyl, alkynyl

$$
\operatorname{Pd}(0) \underset{\text { agent }}{\stackrel{\text { oxidizing }}{\longrightarrow}} \mathrm{Pd}(\mathrm{II})
$$

Scheme 17

\section{3}

\section{Preparation of Fused $\beta$-Lactams with Non-Classical Structure}

\section{1}

\section{Using Cycloaddition Reactions}

Enantiopure carbacepham derivatives $\mathbf{5 4}$ have been prepared in good yields via Lewis acid promoted carbonyl-ene cyclization of the corresponding 2azetidinone-tethered alkenylaldehydes 53 (Scheme 18) [26].<smiles>[R20]C1C(=O)N(C([R2])CC=C(C)C)[C@H]1CO</smiles>

53

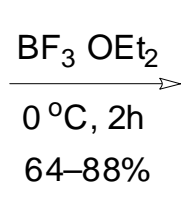

$4-88 \%$

$\mathrm{R}^{1}=\mathrm{Ph}, \mathrm{Bn}, \mathrm{Me}$

$\mathrm{R}^{2}=\mathrm{H}, \mathrm{CO}_{2} \mathrm{Me}$<smiles>[R]C1C[C@H](C(=C)C)[C@H](O)[C@@H]2[C@@H]([R2])C(=O)N12</smiles>

54

\section{Scheme 18}

Starting from some of the above 1-hydroxycarbacephams 54, the synthesis of inner-outer-ring 2-[tert-butyldimethylsilyloxy]dienes 55 with a carbacepham structure and their totally $\pi$-facial endo selective Diels-Alder reactions to structurally novel polycyclic $\beta$-lactams 56 have been reported (Scheme 19) [27]. 


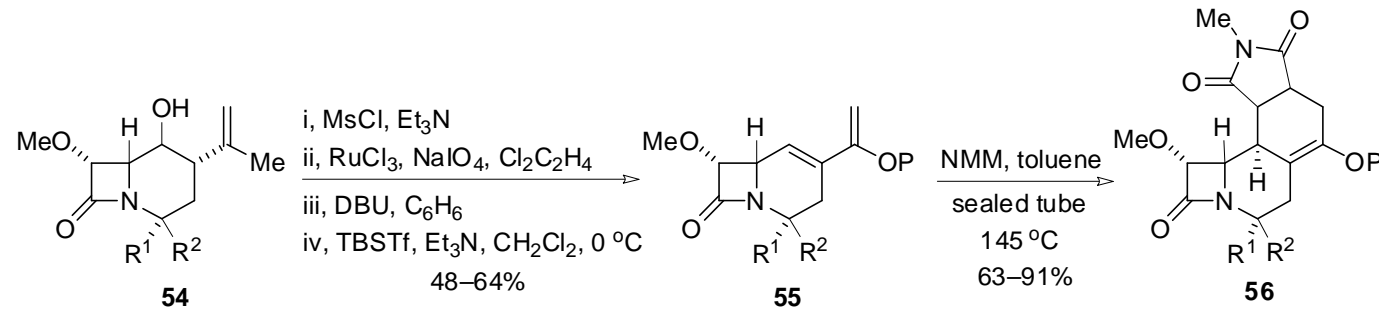

Scheme 19

It has been shown that the combination of ring-closing metathesis and Diels-Alder reaction sequences is a useful synthetic tool for the asymmetric synthesis of novel polycyclic carbacephem derivatives [28]. Thus, enyne metathesis of monocyclic 2-azetidinone $\mathbf{5 7}$ afforded bicyclic compound $\mathbf{5 8}$. This diene was then engaged in a Diels-Alder reaction with dimethyl acetylenedicarboxylate as dienophile to obtain tricyclic $\beta$-lactam $\mathbf{5 9}$ in high yield (Scheme 20).

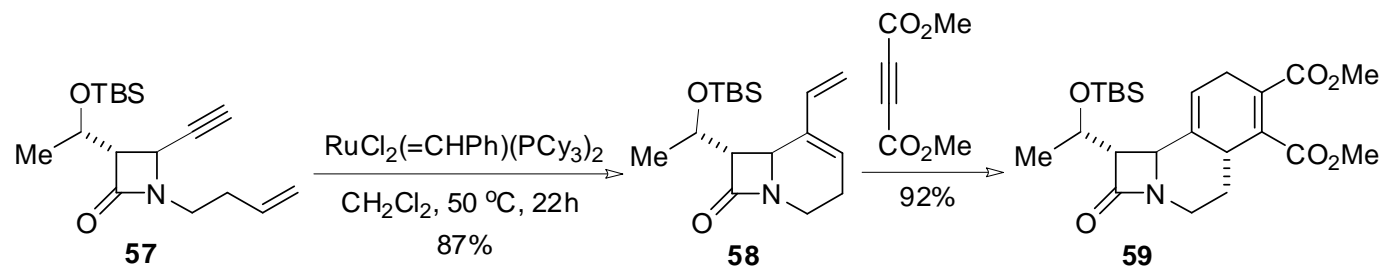

Scheme 20

It has been demonstrated that the intramolecular Diels-Alder reaction is a simple and efficient entry to different tricyclic 2-azetidinones, with a sixmembered ring fused to the $\beta$-lactam nucleus. Homoallylic mesylate $\mathbf{6 0}$ was used for the stereoselective preparation of fused tricyclic 2-azetidinone $\mathbf{6 1}$ through a tandem one-pot elimination-intramolecular Diels-Alder reaction (Scheme 21) [29]. In similar way, starting from mesylate 62, elimination and intramolecular Diels-Alder reaction have allowed the preparation of enantiopure fused tetracyclic $\beta$-lactam 63 (Scheme 22) [30]. 1,4-Cyclohexadiene 63 is prone to undergo aromatization to afford the tetracyclic $\beta$-lactam $\mathbf{6 4}$ containing a benzene ring, as illustrated in Scheme 22.<smiles>C#CCCN1C(=O)[C@H](OC)[C@H]1[C@@H](CC=C)OC</smiles>

60<smiles>CO[C@H]1C(=O)N2CCC3=CCC=C[C@H]3[C@H]12</smiles>

61

Scheme 21 


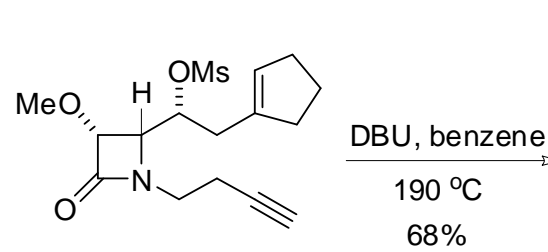

62

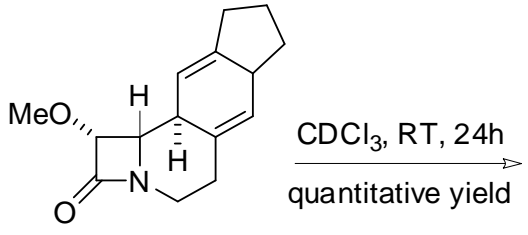

63

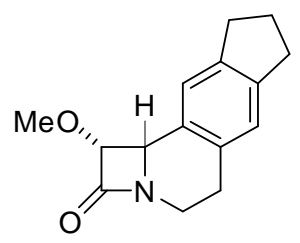

64

Scheme 22

Reaction of enallenes $\mathbf{6 5}$ or allenynes $\mathbf{6 6}$ in the presence of methanesulfonyl chloride at $190{ }^{\circ} \mathrm{C}$ provided tricyclic azetidinones 67 or $\mathbf{6 8}$. These tricycles have been obtained from monocyclic allenols, masked functionalized dienes, via a domino allenol transposition/intramolecular DielsAlder reaction process (Scheme 23) [31]. The mechanism of the one-pot allenoldiene transformation is depicted in Scheme 24. The extremely high selectivity observed in the formation of dienes may point to a pericyclic reaction pathway. Accordingly, the allenol component reacts with methanesulfonyl chloride resulting in a methanesulfonate intermediate. Next, the in situ generated $\alpha$-allenic methanesulfonate 69 suffers a [3,3]-sigmatropic rearrangement, involving the sixmembered cyclic transition structure $\mathbf{7 0}$, to give the corresponding mesyloxydiene counterpart $\mathbf{7 1 .}$ 


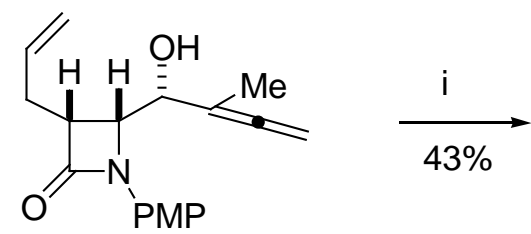

$65 a$

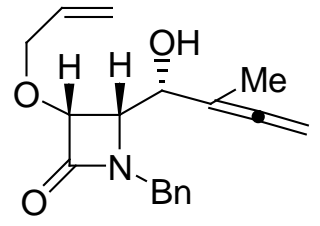

65b

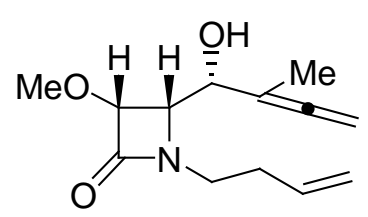

65c

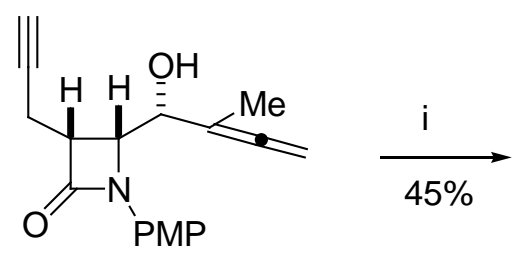

$66 a$

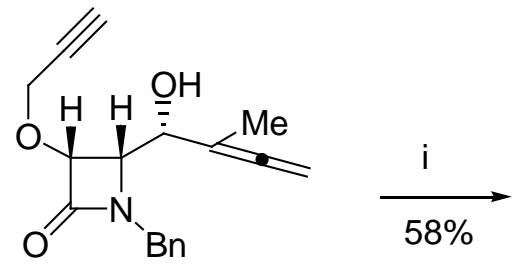

66b

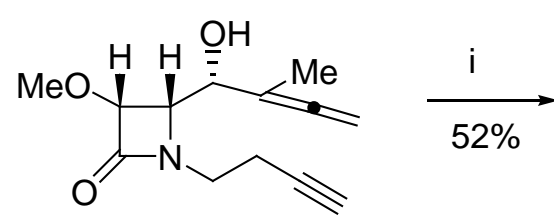

$66 c$

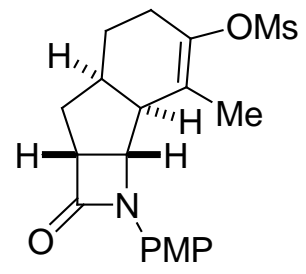

67a (100:0)

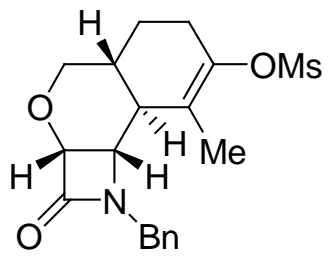

67b (95:5)

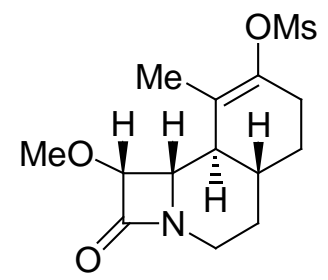

67c (100:0)<smiles>[Y10]N1C(=O)[C@H]2CC3=CCC(OC)=C(C)[C@@H]3[C@@H]21</smiles>

68a (100:0)<smiles>COC1=C(C)[C@H]2C(=CC1)CO[C@H]1C(=O)N(Cc3ccccc3)[C@@H]12</smiles>

68b (85:15)<smiles>COC1=C(C)[C@H]2CC3=CCN(CC[C@@H]2[C@H]1C)C(=O)[C@@H]3OC</smiles>

68c (100:0)

Scheme 23 i) $\mathrm{CH}_{3} \mathrm{SO}_{2} \mathrm{Cl}, \mathrm{Et}_{3} \mathrm{~N}$, toluene, sealed tube, $190{ }^{\circ} \mathrm{C}$. 

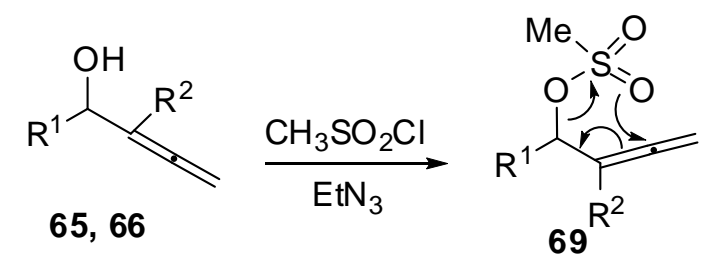

$67,68 \stackrel{\text { IMDA }}{\longleftarrow}$

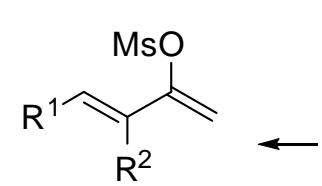

71

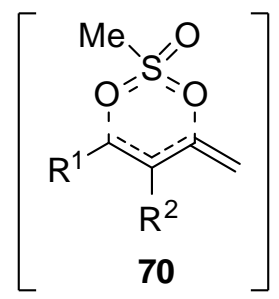

$\mathrm{R}^{1}=$ 2-azetidinone-tethered alkene(alKyne); $\mathrm{R}^{2}=\mathrm{Me}$ or $\mathrm{Ph}$

\section{Scheme 24}

A convenient metal-free methodology for the preparation of structurally novel strained tricyclic $\beta$-lactams containing a cyclobutane ring has been developed. The first examples accounting for the intramolecular [2+2] cycloaddition reaction in $\beta$-lactams have been achieved via the thermolysis of 2 azetidinone-tethered enallenols 72 and $\mathbf{7 4}$ [32]. As shown in Scheme 25, enallenes 72 and 74 undergo efficiently [2+2] thermal cyclization to afford the corresponding strained tricycles $\mathbf{7 3}$ and $\mathbf{7 5}$. The tricyclic ring structures $\mathbf{7 3}$ and $\mathbf{7 5}$ arises from a formal [2+2] cycloaddition of the alkene with the distal bond of the allene, most likely via a diradical intermediate. Exposure of $\mathrm{N}$-methallyl allenols 76 to the above thermal treatment afforded methylenecyclobutane 2-azetidinones 77 as the only products (Scheme 26). Notably, the presence of an internal substituent on the alkene moiety switched the regioselectivity. The successful reversal of regioselectivity in the allene component just by a subtle variation in the substitution at the alkene moiety, is an important development. In the current case, it allowed the preparation of a diverse array of structurally novel strained tricyclic $\beta$-lactams. For example, enantiopure compounds $\mathbf{7 7}$ are remarkable since they bear two quaternary stereogenic centers. 

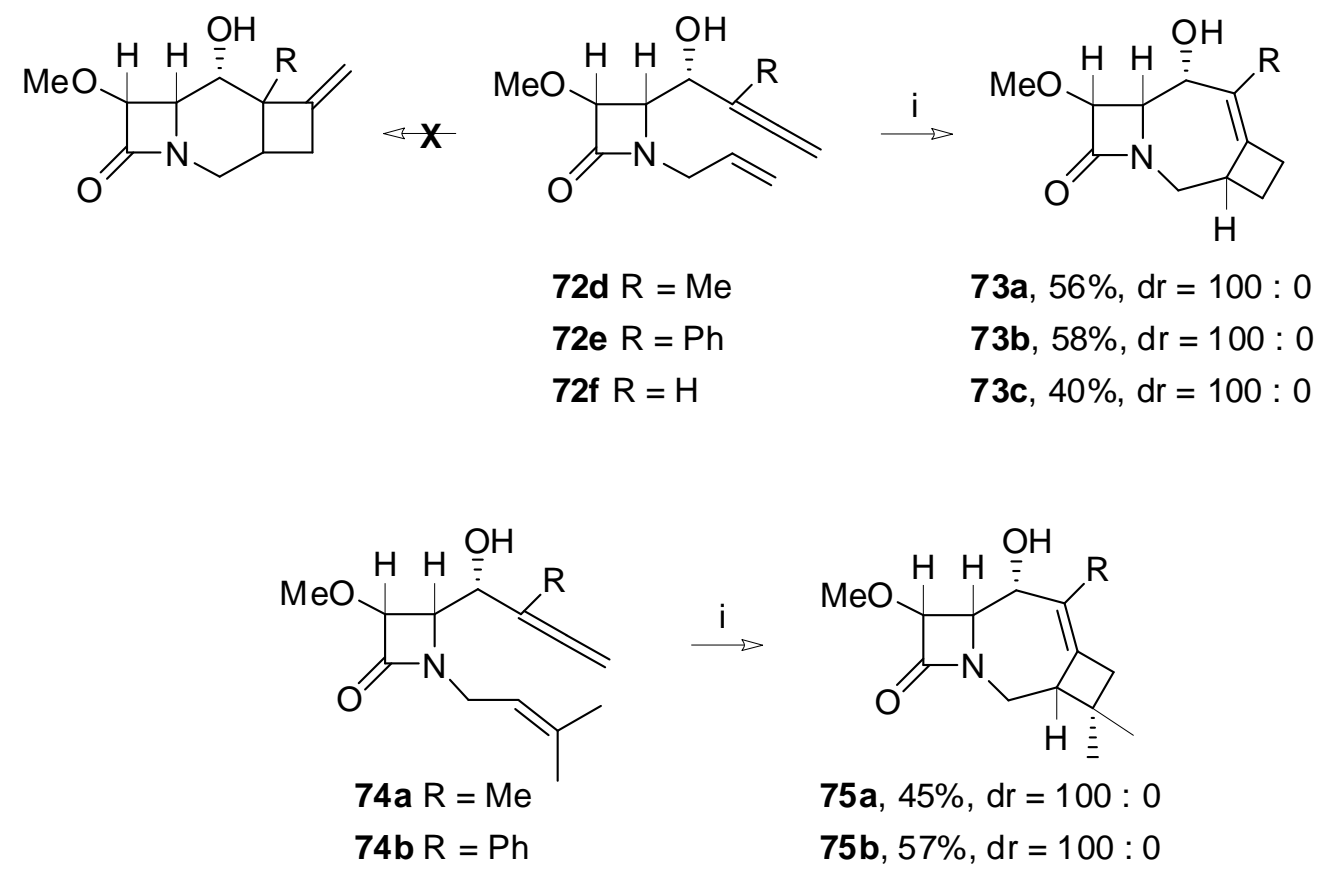

Scheme 25 i) Toluene, sealed tube, $220{ }^{\circ} \mathrm{C}$.

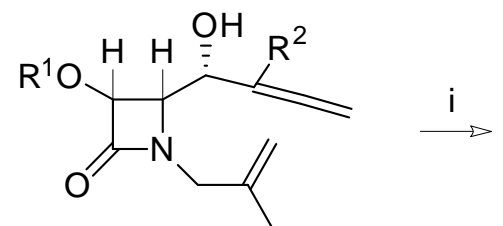

76a $R^{1}=M e, R^{2}=P h$

76b $\mathrm{R}^{1}=\mathrm{Ph}, \mathrm{R}^{2}=\mathrm{Me}$

76c $\mathrm{R}^{1}=\mathrm{Ph}, \mathrm{R}^{2}=\mathrm{Ph}$

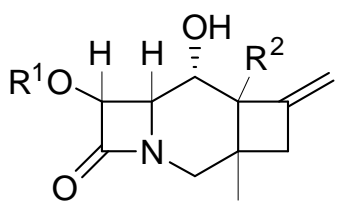

$77 a, 56 \%, d r=100: 0$

$77 b, 52 \%, d r=100: 0$

$77 \mathrm{c}, 57 \%, \mathrm{dr}=100: 0$

Scheme 26 i Toluene, sealed tube, $220{ }^{\circ} \mathrm{C}$.

The formation of fused strained tricycles $\mathbf{7 3}$ and $\mathbf{7 5}$ can be rationalized by a mechanism which includes an exocyclic diradical intermediate $\mathbf{7 8}$ through an initial carbon-carbon bond formation, involving the central allene carbon and the proximal alkene carbon atom (path $A$, Scheme 27). An alternative mechanism for the thermal reaction leading to tricyclic 2-azetidinones $\mathbf{7 3}$ and $\mathbf{7 5}$ is proposed in path $B$ (Scheme 27). This pathway involves an endocyclic diradical intermediate 79 arising from the initial attack of the terminal olefinic carbon onto the distal allene carbon. For both pathways, the final step must be a rapid ring-closure of the diradical intermediates which takes place before bond rotation can occur. 


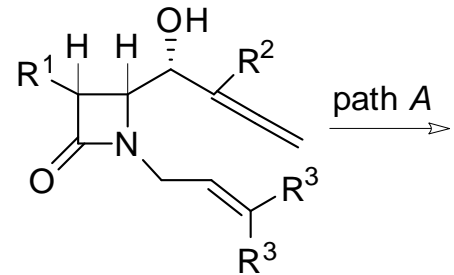

72,74

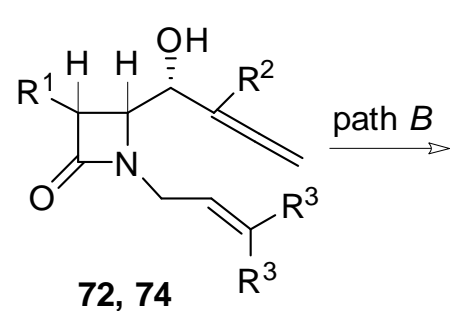

72,74

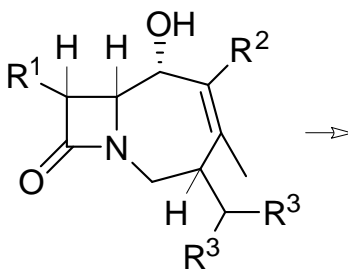

78

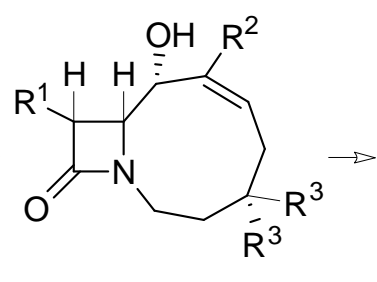

79<smiles>[R]C1=C2CC2([R3])CN2C(=O)C([R])[C@H]1[C@H]2O</smiles>

73,75

73,75

Scheme 27

Analogously, the thermal formation of fused strained tricycles 77 can be rationalized by a mechanism which includes an exocyclic diradical intermediate 80 through an initial carbon-carbon bond formation, involving the proximal allene carbon and the internal alkene carbon atom (path $C$, Scheme 28). The alternative pathway leading to tricyclic 2-azetidinones $\mathbf{7 7}$ is proposed in path $D$ (Scheme 28). This proposal involves an endocyclic diradical intermediate 81 arising from the initial attack of the terminal olefinic carbon onto the central allene carbon. The final ring-closure step of the diradical intermediates account for the cyclobutane formation.

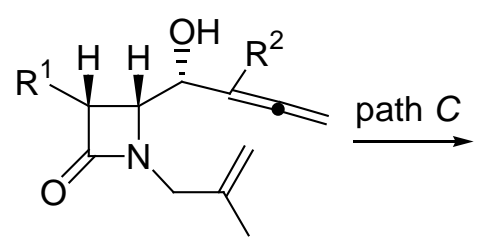

76

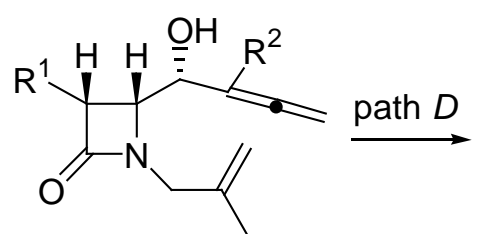

76

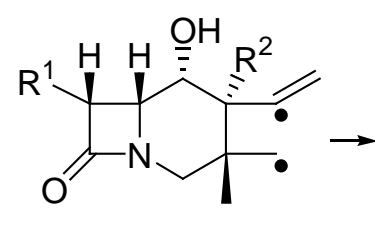

80

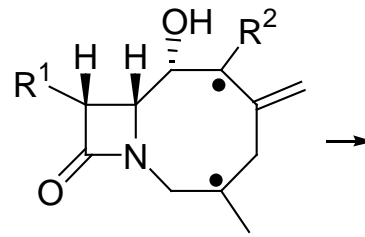

81

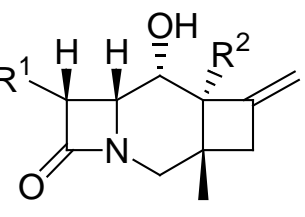

77<smiles>[R]C1[C@H]2C(=O)N1C[C@@]1(C)CC(=C)[C@]1([R2])[C@@H]2O</smiles>

77

Scheme 28

It seems that the regioselectivity in this type of [2+2] cycloaddition reactions is determined by the presence or absence of an alkyl substituent at the internal alkene carbon atom, as the enallenes $\mathbf{7 2}$ and $\mathbf{7 4}$ lacking a methyl group exclusively gave addition at the $\beta, \gamma$-double bond, while the enallenes $\mathbf{7 6}$ bearing a methyl group at the internal olefinic carbon underwent a formal [2+2] cycloaddition reaction at the $\alpha, \beta$-double bond. The pathway $A$ proposed in 
Scheme 27 looks valid for the formation of products 73 and $\mathbf{7 5}$, where when $\mathrm{R}^{3}=$ Me makes the exocyclic diradical most stable and the presence of the double bond makes the allylic radical $\mathbf{7 8}$ favored over the alternate endocyclic vinylic radical 79 in path $B$. However, it could be presumed that for the formation of compounds 77 the pathway $D$ proposed in Scheme 28 is more reasonable. The simultaneous stabilization of the endocyclic diradical $\mathbf{8 1}$ for the presence of the methyl substituent as well as the allylic stabilization makes this radical favored over the exocyclic diradical $\mathbf{8 0}$.

The intramolecular nitrone-alkene cycloaddition reaction using 2azetidinone-tethered alkenyl(alkynyl)aldehydes $\mathbf{8 2 - 8 5}$ as starting materials has been introduced as an efficient route to prepare fused tricyclic aziridine-, isoxazoline- and isoxazolidine- $\beta$-lactams 86-89 [33]. The regioselectivity of this cycloaddition deserves special mention, because depending of the alkene(alkyne) substituent position at the tethered alkenyl(alkynyl)aldehyde, the regioselectivity was tuned from bridged (86) to fused (87-89) tricyclic compounds (Scheme 29). When the alkene substituent was moved from C3 to N1 in the 1,4-tethered alkenylaldehyde, the bridged $\mathrm{N}, \mathrm{O}$-heterocycles $\mathbf{8 6}$ were formed as the exclusive products. Formation of the bridged-ring products $\mathbf{8 6}$ is worthy of note because only fused-ring products have been found in the intramolecular nitrone-alkene cycloaddition reactions of related $\mathrm{N}$-alkenyl-2-prolinaldehyde and related cyclicbridged alkenylaldehydes. It is possible that, because of the rigid angular disposition imparted by the planar lactam group, the fused-ring transition state increases in energy thereby becoming uncompetitive with the usually unfavored bridged-ring transition state. The aziridine carbaldehyde $\mathbf{8 8}$ may arise by thermal sigmatropic rearrangement. 
<smiles>C=CNN1C(=O)C(Oc2ccccc2)C1C=O</smiles>

82<smiles>[Y6]N1C(=O)[C@H](OCC=C)[C@H]1C</smiles>

83

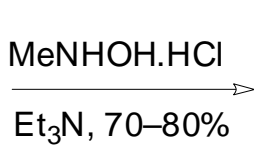

${ }_{3} \mathrm{~N}, 70-80 \%$

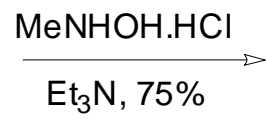

$\mathrm{Et}_{3} \mathrm{~N}, 75 \%$

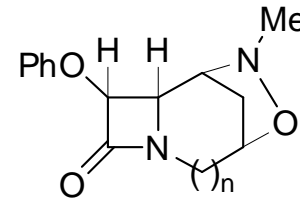

$86 n=1-3$<smiles>C#CCCN1C(=O)C(O)C1C=O</smiles>

$\mathrm{MeNHOH} . \mathrm{HCl}$

$\mathrm{Et}_{3} \mathrm{~N}, 55 \%$<smiles>CN1CC2C(COC3C(=O)N([Y6]#N)C32)CO1</smiles>

87<smiles>CCS(=O)(=O)c1ccccc1</smiles>

88<smiles>CCN(CC)S(=O)(=O)ONC#CCCCN1C(=O)C(O)C1C=O</smiles>

85<smiles>CN1OC=C2CCCN3C(=O)C(O)(O)[C@H]3[C@H]21</smiles>

89

Scheme 29

The reactivity of $2 \mathrm{H}$-azirines $\mathbf{9 1}$ and $\mathbf{9 3}$ as 1,3-dipolarophiles towards $\beta$ lactam based azomethine ylides derived from oxazolidinones 90 has been investigated [34]. The reaction of 3-(4-methoxyphenyl)-2 $H$-azirine 91 with oxazolidinone $\mathbf{9 0}$ did not afford the expected cycloadduct. However, compound 92 was isolated as the major product in 41\% yield (Scheme 30). In contrast, by using a nitroaryl moiety at the 3-position of the azirine ring, the initial cycloadducts 94 were prevented from further fragmentation (Scheme 31). Subsequent release (by nitro group reduction and protection) of the corresponding anilide then triggers the desired $\mathrm{C}-\mathrm{N}$ bond cleavage. It has also been demonstrated that depending on the nature of the ester-protecting group (94a vs. 94b) these conditions lead to either 95 or $\mathbf{9 6}$, both of which are novel azacepham derivatives.<smiles>O=C(O)[C@H]1C(=O)CC2CC(=O)N21</smiles>

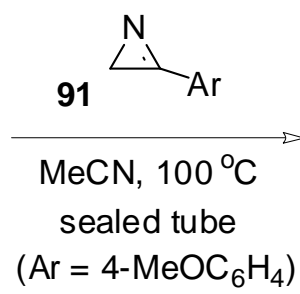

$41 \%$

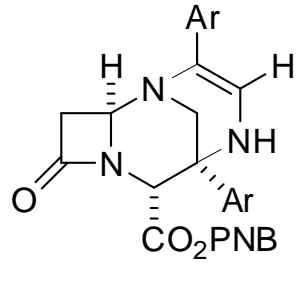

92

Scheme 30 


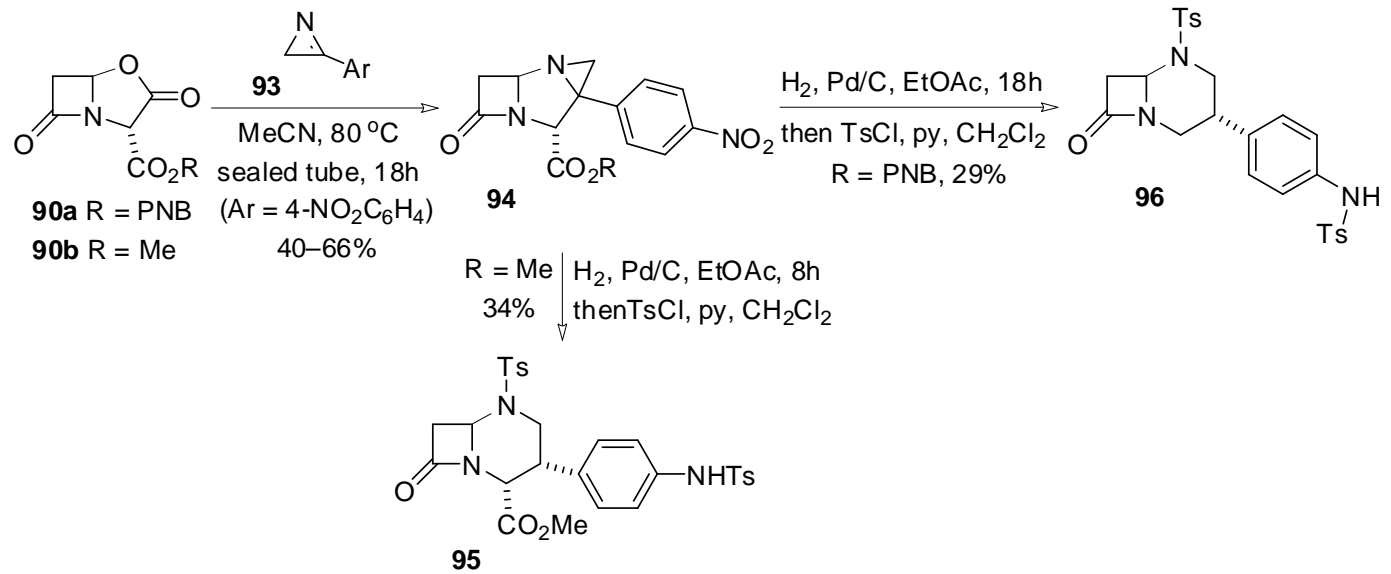

Scheme 31

\section{2}

\section{Using Radical Reactions}

The reductive opening of epoxy- $\beta$-lactam 97 with titanocene(III) chloride gives rise to a benzyl radical that can be trapped by intramolecular $\pi$ systems to give the tricyclic 2-azetidinone 98 (Scheme 32) [35].<smiles>CO[C@H]1C(=O)N(C2=CC(C3COC(C)(C)O3)OC2=O)[C@H]1C1OC1c1ccccc1</smiles>

97

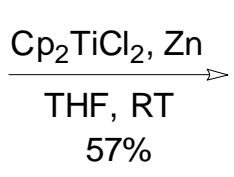

$57 \%$<smiles>CO[C@H]1C(=O)N2C3C(=O)OC(C4COC(C)(C)O4)C3[C@H](c3ccccc3)[C@@H](O)C12</smiles>

98

Scheme 32

An approach (racemic and asymmetric) to benzofused tricyclic $\beta$-lactams including benzocarbapenems as well as benzocarbacephems, through intramolecular aryl radical cyclization of 2-azetidinone-tethered haloarenes has been reported [36]. Haloaryl $\beta$-lactams 99-103 were reacted with tributyltin hydride and AIBN in benzene at reflux to give the expected benzocarbapenems 104 and 106 and benzocarbacephems 105, 107 and 108 in good yields as single diastereomers after chromatographic purification (Scheme 33, Table 1). These intramolecular radical reactions were carried out under standard dilution conditions, and did not require the use of high dilution techniques. Removal of the organotin halides by a solution of KF in water is essential for an appropriate chromatographic purification of compounds 104-108. With the exception of the reaction of 101b, neither cyclization products different from 104-108 nor reduction products were detected in the ${ }^{1} \mathrm{H}-\mathrm{NMR}$ spectra of the crude reaction mixtures. The full stereoselectivity of the radical cyclisation is particularly 
attractive, being independent of the substitution at C3 or N1 on the $\beta$-lactam ring. In addition, 2-azetidinones bearing styryl or carboxymethyl substituents at C4 underwent 5(or 6)-exo-trig radical cyclization to benzocarbapenems and benzocarbacephems 104-108 in a totally regioselective fashion, as expected when the radical acceptor has a radical-stabilizing moiety at the $\beta$-position. The radical reaction of the crotonaldehyde-imine derived $\beta$-lactam $\mathbf{1 0 1 b}$, lacking a radicalstabilizing moiety, deserves special mention. Haloalkenyl $\beta$-lactam 101b formed, along with benzocarbapenem 106b benzocarbacephem 109 (Scheme 34).
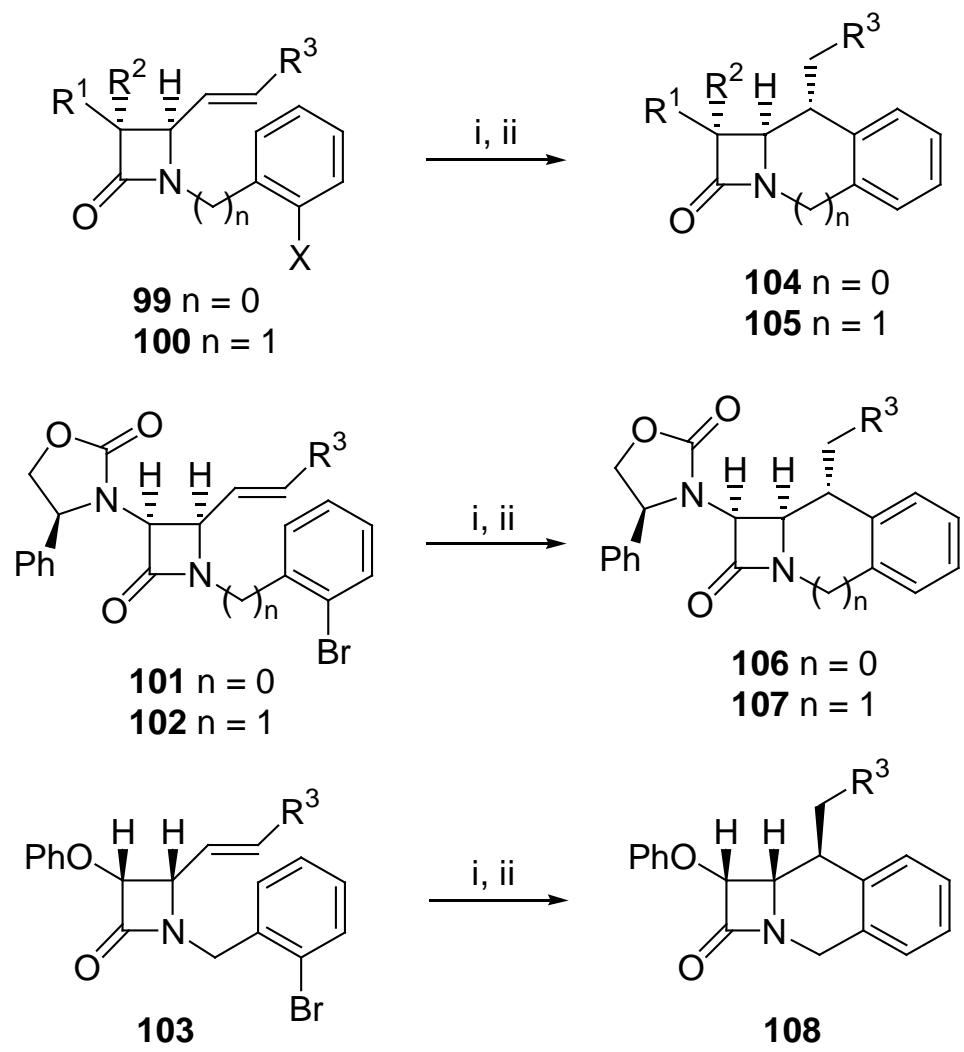

Scheme 33 i) $\mathrm{Bu}_{3} \mathrm{SnH}$ (1.2 eq), AIBN (0.1 eq), benzene, reflux, 1-2 h; ii 10\% aqueous KF, 30 min.

Table 1. Preparation of Fused Tricyclic $\beta$-Lactams 104-108 


\begin{tabular}{|c|c|c|c|c|c|c|c|}
\hline substrate $^{a}$ & $\mathrm{R}^{1}$ & $\mathrm{R}^{2}$ & $\mathrm{R}^{3}$ & $X$ & $\mathrm{n}$ & product $^{a}$ & yield $(\%)^{b}$ \\
\hline 99a & $\mathrm{Me}$ & $\mathrm{Me}$ & $\mathrm{Ph}$ & $\mathrm{Br}$ & 0 & $104 a$ & 65 \\
\hline $99 b$ & $\mathrm{PhO}$ & $\mathrm{H}$ & $\mathrm{Ph}$ & $\mathrm{Br}$ & 0 & 104b & 66 \\
\hline cis-99c & $\mathrm{BnO}$ & $\mathrm{H}$ & $\mathrm{Ph}$ & I & 0 & cis-104c & 60 \\
\hline trans-99c & $\mathrm{BnO}$ & $\mathrm{H}$ & $\mathrm{Ph}$ & I & 0 & trans-104c & 65 \\
\hline $100 a$ & $\mathrm{PhO}$ & $\mathrm{H}$ & $\mathrm{Ph}$ & $\mathrm{Br}$ & 1 & $105 a$ & 50 \\
\hline 100b & $\mathrm{BnO}$ & $\mathrm{H}$ & $\mathrm{Ph}$ & $\mathrm{Br}$ & 1 & $105 b$ & 61 \\
\hline $101 a$ & & & $\mathrm{Ph}$ & & 0 & $106 a$ & 70 \\
\hline 101b & & & $\mathrm{Me}$ & & 0 & $106 b$ & 30 \\
\hline 102 & & & $\mathrm{Ph}$ & & 1 & 107 & 57 \\
\hline $103 a$ & & & $\mathrm{CO}_{2} \mathrm{Me}$ & & & $108 a$ & 64 \\
\hline $103 b$ & & & $\mathrm{Me}$ & & & $108 b$ & 47 \\
\hline
\end{tabular}

${ }^{a}$ Compounds 99, 100, 104 and 105 are racemic. ${ }^{b}$ Yield of pure, isolated product with correct analytical and spectral data.

$(S)-$<smiles>C/C=C/[C@H]1C(=O)C(=O)N1c1ccccc1Br</smiles>

101b
(S)-<smiles>CC[C@H]1c2ccccc2N2C(=O)C([O])[C@H]12</smiles>

$106 b$
(S)<smiles>CO[C@H]1C(=O)N2c3ccccc3C(C)C[C@H]12</smiles>

$(S)-O x=(S)-4-$ phenyl-2-oxo-1,3-oxazolidin-3-yl

Scheme 34 i) $\mathrm{Bu}_{3} \mathrm{SnH}$ (1.2 eq), AIBN (0.1 eq), benzene, reflux, 1.5 h; ii 10\% aqueous KF, 30 min.

A mechanistic explanation for tricyclic $\beta$-lactams 104-109 is depicted in Scheme 35. The complete selectivity observed in the formation of benzocarbapenems 104 and 106 and benzocarbacephems 105, 107 and 108 must be due to the preference of the radical intermediates for the conformation depicted in Scheme 36 for these cyclizations. 


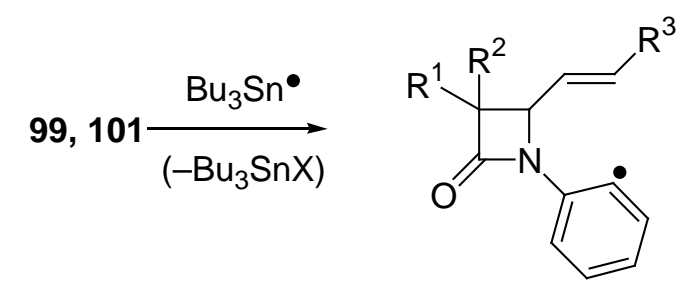

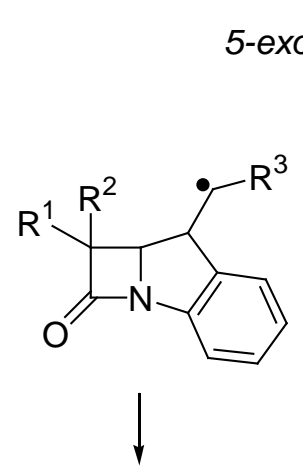

104,106
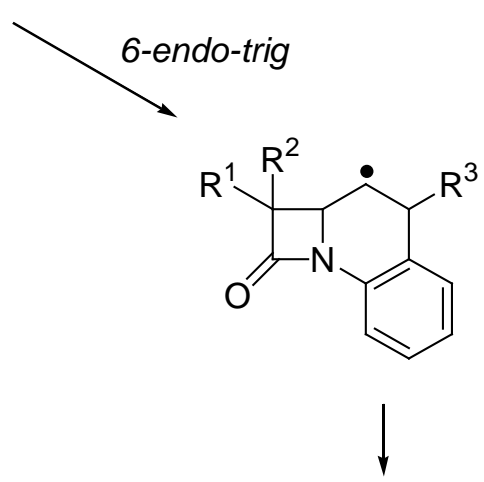

109

Scheme 35
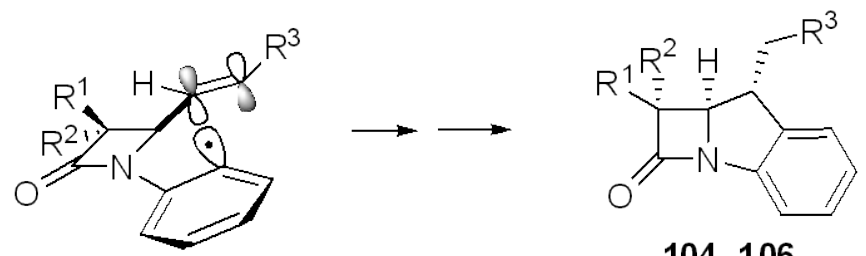

104,106
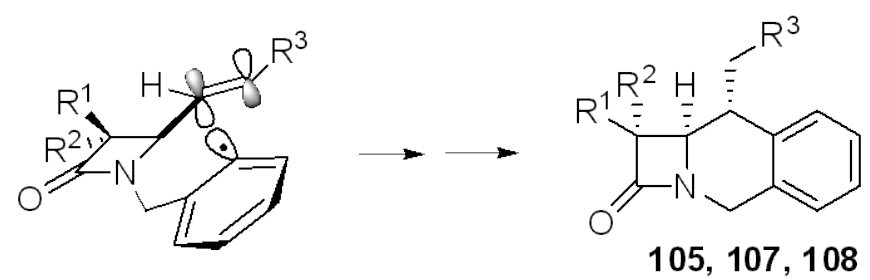

Scheme 36

The extension of the above radical intramolecular cyclization of $\mathrm{N}$ haloaryl- $\beta$-lactams to 2-azetidinones bearing the proradical center at C3 was also explored. The treatment of haloarenes 109a-c under similar conditions for the preparation of benzocarbapenems and benzocarbacephems 104-108 gave the fused tricyclic $\beta$-lactams 110a-c (Scheme 37, Table 2). Compounds 110a and 110b were obtained as mixtures of diastereomers, which are epimers at the newly formed C5 stereocenter, while the amino derivative 110c could be prepared as a single isomer. 
<smiles>[Y7]C=C1C(Oc2ccccc2Br)C(=O)N1P(=O)(F)c1ccccc1</smiles>

109

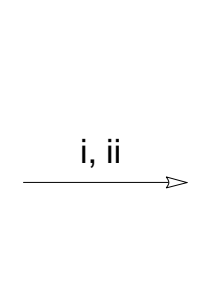

Scheme 37 i) $\mathrm{Bu}_{3} \mathrm{SnH}$ (1.2 eq), AIBN (0.1 eq), benzene, reflux, 1 h; ii) 10\% aqueous KF, 30 min.

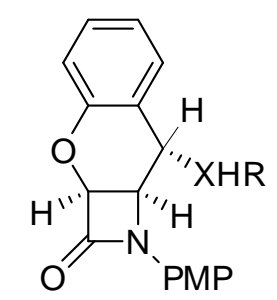

110

Table 2. Preparation of Fused Tricyclic $\beta$-Lactams 110

\begin{tabular}{cccccc} 
substrate $^{a}$ & $\mathrm{R}$ & $\mathrm{X}$ & d.r. $^{c}$ & product $^{a}$ & yield $(\%)^{b}$ \\
\hline 109a & $\mathrm{Ph}$ & $\mathrm{CH}$ & $85: 15$ & $\mathbf{1 1 0 a}$ & 69 \\
109b & $\mathrm{CO}_{2} \mathrm{Me}$ & $\mathrm{CH}$ & $70: 30$ & $\mathbf{1 1 0 b}$ & 56 \\
109c & $\mathrm{Bn}$ & $\mathrm{N}$ & $>95: 5$ & 110c & 60
\end{tabular}

${ }^{a} \mathrm{PMP}=4-\mathrm{MeOC}_{6} \mathrm{H}_{4} \cdot{ }^{b}$ Compounds 109 and 110 are racemic. ${ }^{c}$ The ratio was determined by integration of well-resolved signals in the ${ }^{1} \mathrm{H}$ NMR spectra of the crude reaction mixtures before purification. ${ }^{d}$ Yield of pure product (mixture of isomers).

The formation of rings with more than seven atoms have unfavorable rates because the addition step is often too slow to allow it to compete successfully with other pathways open to the radical intermediate. In stannane based chemistry for example, premature hydrogen abstraction from the organotin hydride is difficult to avoid. However, Baylis-Hillman adducts 111 derived from enantiopure 1alkenyl (or alkynyl)-4-azetidinone-2-carbaldehydes are used for the stereoselective and divergent preparation of highly functionalized bicycles 112 and 113 fused to medium-sized heterocycles (Scheme 38) [37]. The BaylisHillman reaction using non-racemic protected $\alpha$-amino aldehydes has been attempted with limited success, due to partial racemization of the chiral aldehyde by DABCO after prolongate exposure times. However, this is not the case of 4oxoazetidine-2-carbaldehydes, because on reacting with various activated vinyl systems the corresponding adducts can be prepared almost as single diastereoisomers. The diastereofacial preference of this addition reaction for synaddition to the aldehyde moiety was interpreted by the Felkin-Anh model. Formation of $N$-fused bicyclic $\beta$-lactams 112 and 113 can be explained in terms of a competition between a tandem radical Michael addition/endo-cyclisation and a tandem radical addition/Michael addition, depending on the electronic nature of the radical promoter (Scheme 39). It is known that nucleophilic radicals react more rapidly with electron poor alkenes than with electron rich alkenes or alkynes, and conversely, electrophilic radicals react more rapidly with electron rich alkenes than electron poor alkenes. In the above case, Baylis-Hillman adducts may react through two different pathways to give the bicyclic systems. The more 
nucleophilic benzylic radical would favor formation of compounds 112, while the more electrophilic radicals, such as $\mathrm{PhS} \cdot$ and $\mathrm{Ph}_{3} \mathrm{Sn}$, should promote formation of compounds 113. Alternatively, the differences in reactivity between the benzylic and the thiyl and stannyl radicals, respectively, could be explained by other considerations. Thus, for the thiyl and stannyl radicals the initial addition to the double bond is fast but reversible. Since the cyclization is a slow reaction, it can not compete with fragmentation. However, the addition to the triple bond is irreversible and therefore only products deriving from addition to the triple bond are isolated. Addition of the benzylic radical to the double bond of course is not reversible.

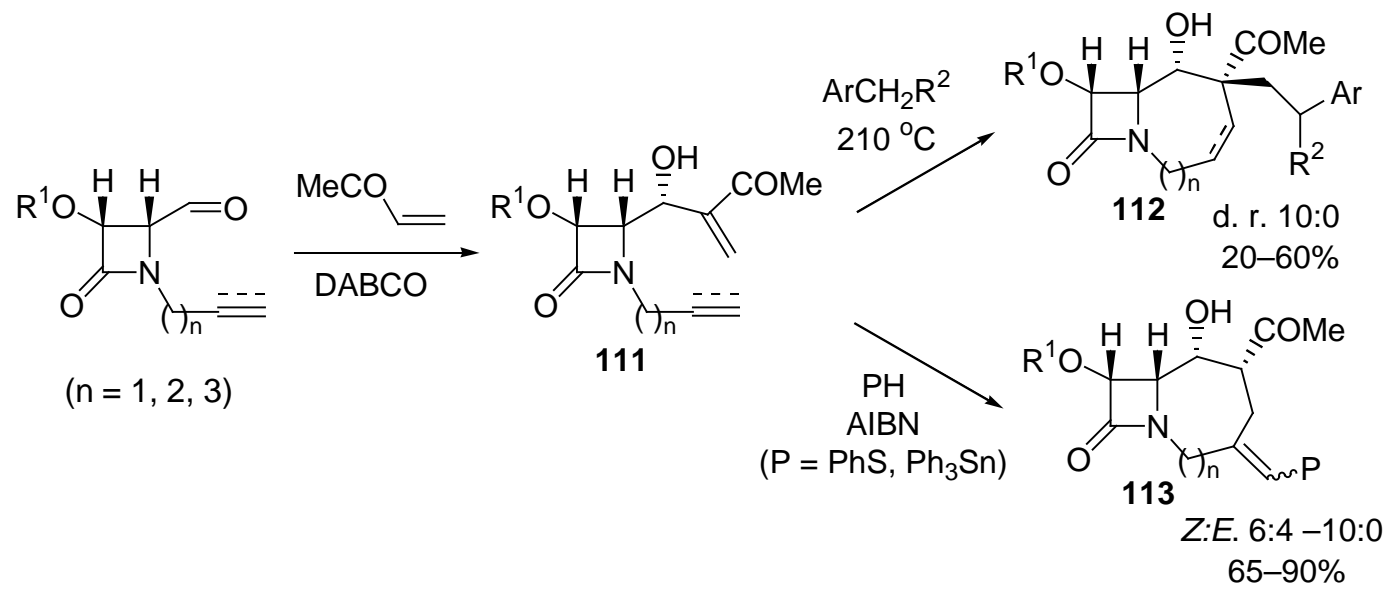

Scheme 38 

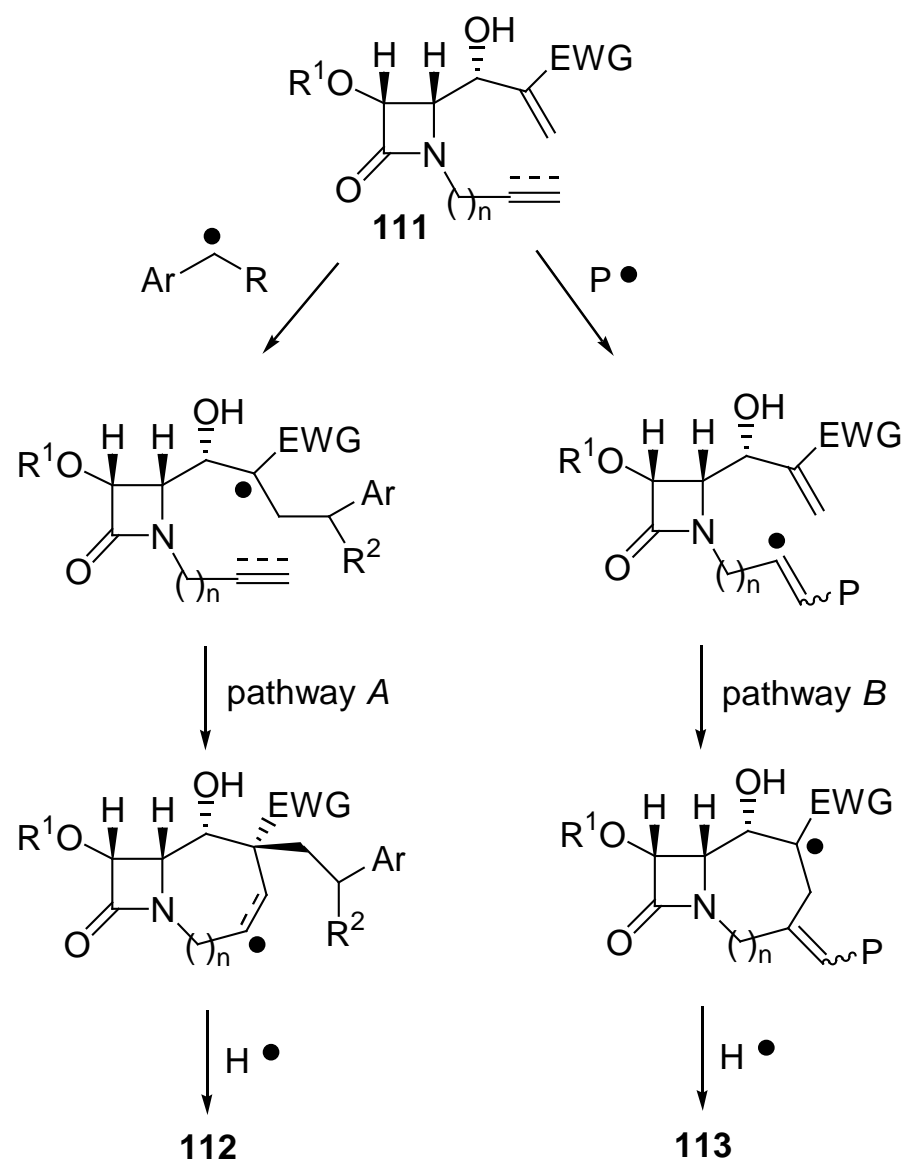

Scheme 39

The synthesis of $N$-fused tricyclic $\beta$-lactams involving a radical cascade sequence in enyne 2-azetidinones 114 and 115 bearing a methylenecyclopropane unit has been reported [38]. Slow addition of $\mathrm{Bu}_{3} \mathrm{SnH} / \mathrm{AIBN}$ to a refluxing solution of $\mathbf{1 1 4}$ gave tricyclic vinylstannane $\mathbf{1 1 6}$ as a single stereoisomer in $42 \%$ yield, whereas cyclization of $\mathbf{1 1 5}$ under identical conditions gave fused heterocycles 117 and 118 in 73 and 11\% yield, respectively, in all three cases via a 7-endo cyclization. Treatment of vinyl stannanes 117 and 118 with PPTS in dichloromethane yielded a common tricyclic product 119 (Scheme 40). 

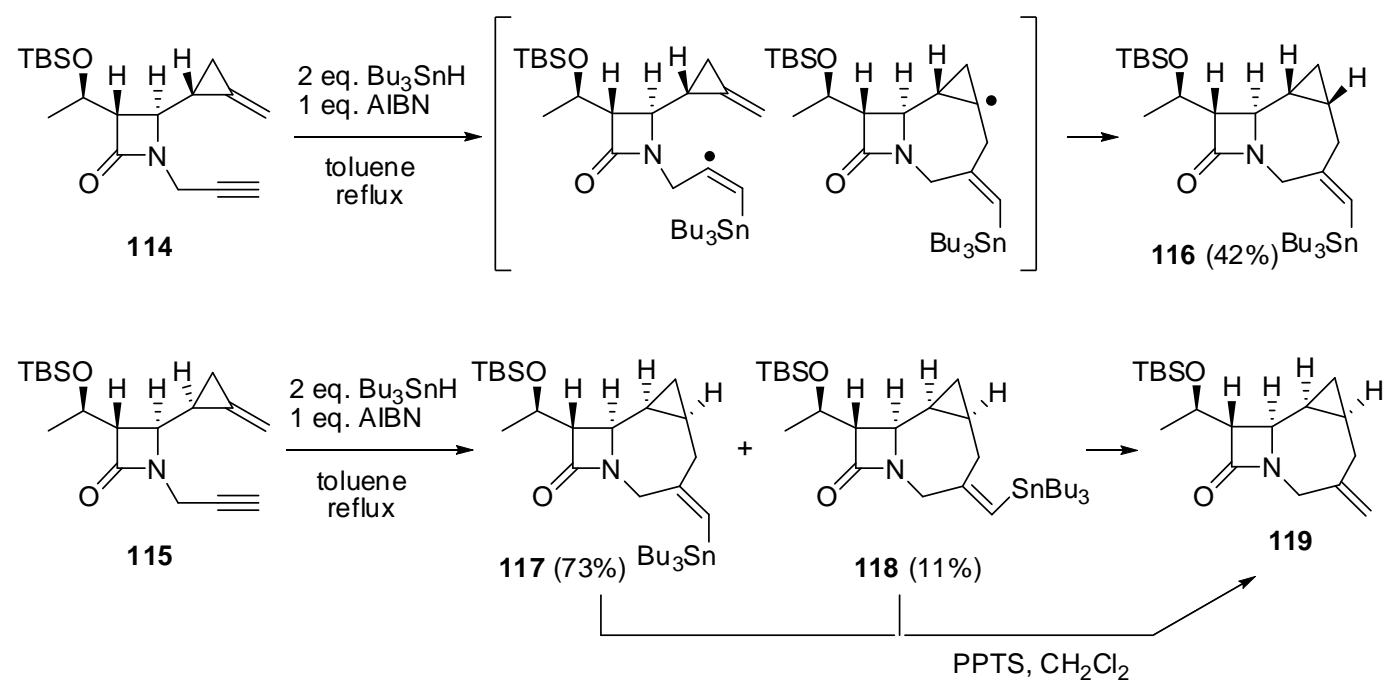

Scheme 40

A different report provided the access to a highly strained tetracyclic [3.6.6.4] ring system containing a fused tetrahydropyran- $\beta$-lactam moiety [39]. The radical precursors 120 were easily accessible via cycloaddition reaction of the appropriate imines with a chiral chloride derived from enantiomerically pure (+)3-carene. When compounds 120 were subjected to radical cyclization conditions, fused tetracyclic $\beta$-lactams $\mathbf{1 2 1}$ were achieved as a single diastereomer (Scheme 41). The high stereoselectivity in this 6-exo-trig cyclization was rationalized by invoking a six-membered transition state mode. The conformational constraint within the rigid bicyclic system and $\beta$-lactam framework with a flexible oxygen tether does not allow the system to go through the generally favored 6-exo-chair transition state, and now an energetically favored six-membered boat-like transition state seems to be involved.

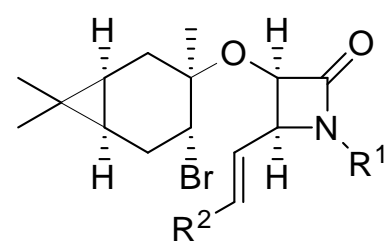

120

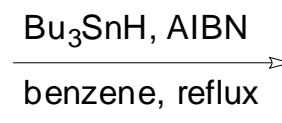

benzene, reflux

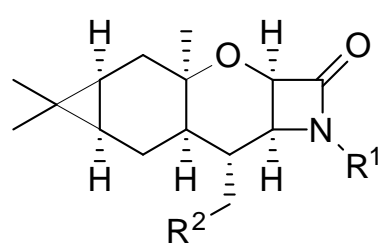

$121(60-96 \%)$

Scheme 41

Six-, seven-, or eight-membered bicyclic 2-azetidinones have been prepared through triphenyltin hydride-promoted intramolecular free radical cyclization reaction of $\beta$-lactam-tethered bromodienes (Scheme 42) [40]. The tinpromoted radical reaction of bromodienic alcohol 122a gave the eight-membered ring fused- $\beta$-lactam 123 together with the homoallylic alcohol 124. The free radical cyclization proceeded elegantly in bromodiene 122b to provide the desired non-conventional bicyclic $\beta$-lactam 125 as single isomer. The 1-vinyl-3-hydroxy6-hexenyl radical (radical numbering) derived from bromide 122c afforded the 
seven-membered ring fused bicycle 126 prevailing over the isomeric product 127 containing a six-membered ring. Triphenyltin hydride-promoted cyclization of bromodiene 122d afforded the expected fused 2-azetidinone $\mathbf{1 2 8}$ as a single isomer in fair yield.<smiles>C=CCN1C(=O)C(OC)C1[C@H](O)CC(=C)Br</smiles>

$122 a$

$\mathrm{CO}_{2} \mathrm{Me}$<smiles>C=C(Br)CC(O)C1C(O/C=C/C)C(=O)N1P(N)F</smiles>

$122 b$<smiles>C=CC1C(=O)N(P)C1[C@H](O)CC(=C)Br</smiles>

$122 \mathrm{c}$<smiles>C=C(Br)C[C@H](O)C1C(C(=C)C)C(=O)N1P(N)O</smiles>

$122 d$ a)<smiles>C=C1CCCN2C(=O)C(OC)C2C(O)C1</smiles>

$123(57 \%)$<smiles>C=C1CC(O)C2C(OC1CC(C)=O)C(=O)N2PN</smiles>

$125(46 \%)$

a)<smiles>C=C1CCC2C(=O)N(P)C2C(O)C1</smiles>

$126(37 \%)$<smiles>C=C1CC(O)C2C(C1=O)C(=O)N2[N+]#P</smiles>

$127(29 \%)$

a)<smiles>C=C1CC(C)C2C(=O)N(P)C2C(O)C1</smiles>

$128(40 \%)$

Scheme 42 a) $\mathrm{Ph}_{3} \mathrm{SnH}$ (1.2 eq), AIBN (0.1 eq), benzene, reflux.

The synthesis of eight- and nine-membered rings fused to 2-azetidinones has been investigated using radical chemistry in $\beta$-lactam ene adducts bearing an extra alkyne tether [30]. The tin-promoted radical cyclization proceeded in enynes 129a and 129b to provide the desired non-conventional bicyclic $\beta$-lactams as single isomers in moderate yields (Scheme 43). Treatment of vinylic stannane 130a with PTSA in $\mathrm{CH}_{2} \mathrm{Cl}_{2}$ yielded the destannilated eight-membered fused adduct 131. 


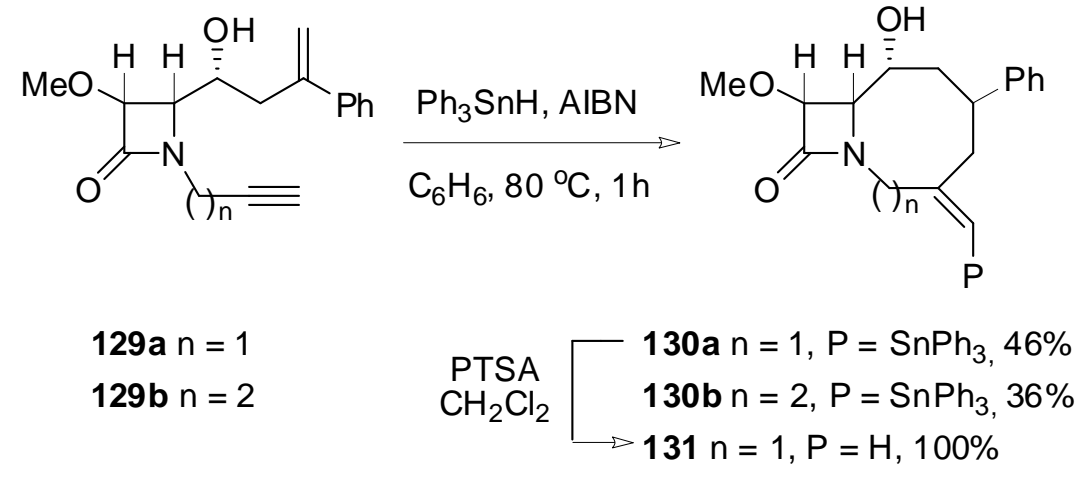

Scheme 43

A novel approach to racemic and enantiopure non-conventional fused biand tricyclic $\beta$-lactams has been developed by using regio- and stereocontrolled intramolecular free radical reactions in monocyclic 2-azetidinone-tethered allenynes and haloallenes [41]. In an initial study, we found that allenynol 132a when heated in the presence of triphenyltin hydride and AIBN in benzene solution, gave the bicyclic $\beta$-lactam 133a in 64\% yield as a single regio- and Zisomer. Tin-promoted cyclization of allenynol 132b afforded the expected 2azetidinone 133b containing a medium-sized ring. Allenynol anti-132c having the alkynyl side chain at C3 instead of N1 underwent cyclization to afford the C3-C4 fused $\beta$-lactam 133c. Similar behavior was observed for the free radical cyclization of allenynone 132d, which afforded the heterobicyclic ketone 133d. Interestingly, only bicycles 133 were found as a consequence of a totally regioselective radical cyclization onto the central carbon (Scheme 44). Neither the endo-cyclized product nor the exo-cyclized product was detected. 

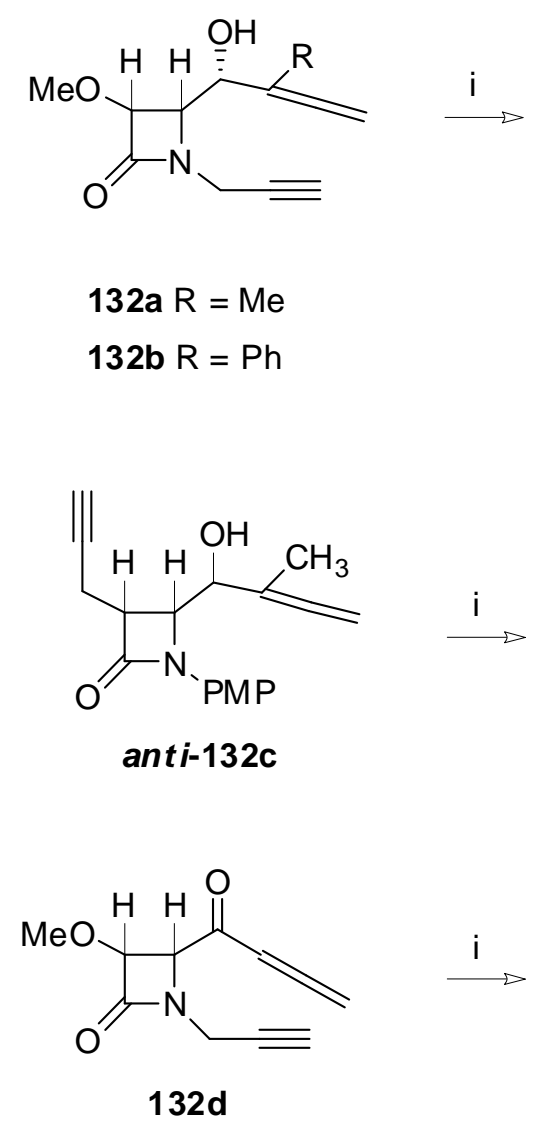

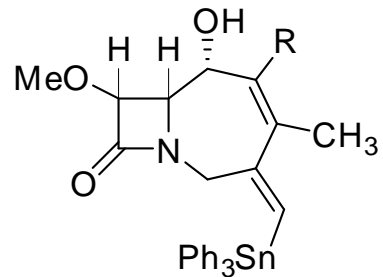

133a $\mathrm{R}=\operatorname{Me}(64 \%, Z: E=100: 0)$

133b $\mathrm{R}=\mathrm{Ph}(49 \%, Z: E=100: 0)$<smiles>CC1=C(C)N2C(=O)C(C/C([SnH2])=C\[SnH2])C2[C@H]1O</smiles>

133c $(47 \%, Z: E=0: 100)$

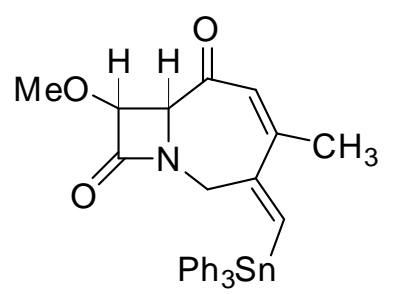

133d $(44 \%, Z: E=100: 0)$

Scheme 44 i) $\mathrm{Ph}_{3} \mathrm{SnH}$ (1.2 eq), $\operatorname{AIBN}(0.1 \mathrm{eq})$, benzene, reflux.

The extension of the above radical cyclization of 2-azetidinone-tethered allenynes to bromovinyl and haloaryl allenes bearing the proradical center at N1 was explored. The tin-promoted radical reaction was also useful in the conversion of the $\beta$-lactam allenes 134a and 134b with a bromopropenyl group substituted at the nitrogen atom, into the corresponding bicyclic systems 135a and 135b with similar efficiency and selectivity (Scheme 45 ). The treatment of $\beta$-lactam allenes 136a-d having a bromo- or iodophenyl group ( $N$-tethered) under similar conditions for the preparation of bicycles 133 and 135 gave the fused tricyclic $\beta$ lactams 137a-c containing a central seven-membered ring (Scheme 46). Benzofused $\beta$-lactams 137 can be considered as superior cyclohomologous of benzocarbapenems and benzocarbacephems, which have been designed as suicide inactivators of $\beta$-lactamases.

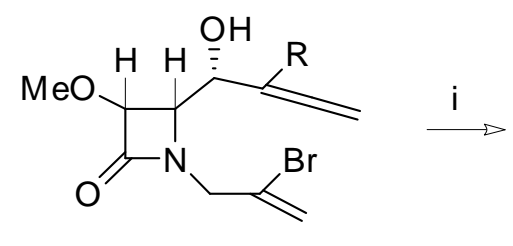<smiles>[R]C1=C(C)C(=C)CN2C(=O)C(OC)C2C1O</smiles>

$$
\begin{array}{ll}
\text { 134a } R=M e & \text { 135a } R=M e(67 \%) \\
\text { 134b } R=P h & \text { 135b } R=P h(61 \%)
\end{array}
$$

Scheme 45 i) $\mathrm{Ph}_{3} \mathrm{SnH}$ (1.2 eq), AIBN (0.1 eq), benzene, reflux. 

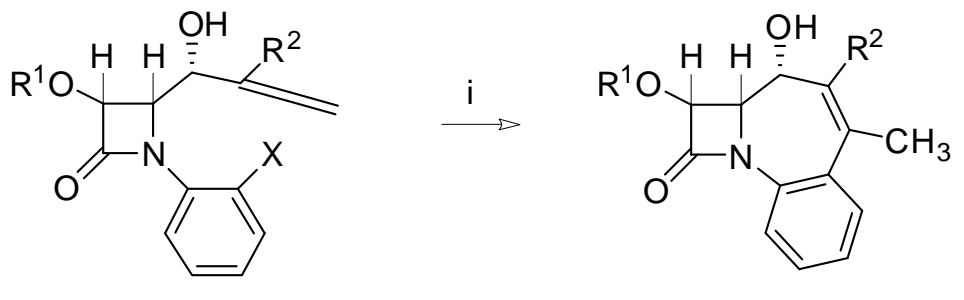

$$
\begin{aligned}
& \text { 136a } R^{1}=M e, R^{2}=M e, X=B r \\
& \text { 136b } R^{1}=M e, R^{2}=P h, X=B r \\
& \text { 136c } R^{1}=M e, R^{2}=M e, X=I \\
& 136 d R^{1}=P h, R^{2}=M e, X=I
\end{aligned}
$$$$
137 \text { a (52\%) }
$$$$
137 \text { b (46\%) }
$$$$
137 \text { a }(50 \%)
$$$$
\text { 137c (41\%) }
$$

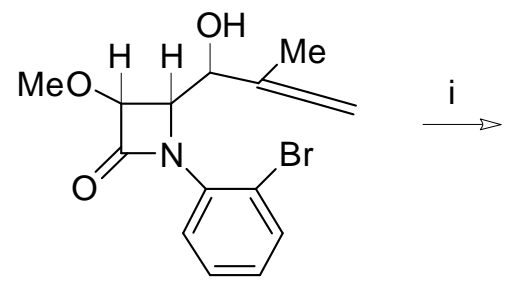

anti-136a<smiles>COC1C(=O)N2c3ccccc3C(C)=C(C)C(O)C12</smiles>

anti-137a (42\%)

Scheme $46 \mathrm{i} \mathrm{Ph}_{3} \mathrm{SnH}$ (1.2 eq), AIBN (0.1 eq), benzene, reflux.

It is presumed that the stannyl radical, by addition to the terminal position of the triple bond in allenynes 132, or through bromine abstraction in bromovinyl and haloaryl allenes 134 and 136 gives the vinylic radical intermediates 138 and 142 in the propagation step, followed by cyclization toward the central carbon bond of the allene moiety to give in a total regio- and stereoselective fashion fused cycles 133, 135 and 136 via allylic radical intermediates 139 and 143 . While both endo- and exo-cyclizations of radical intermediates 138 and 142 would give vinylic radicals 140, 144 and 141, 145, respectively, central-cyclization would lead to the energetically more favored allylic radicals 139 and 143 (Schemes 47 and 48).<smiles>[R]C(=C)C(O)C1C([R4])C(=O)N1CC#C</smiles>

132

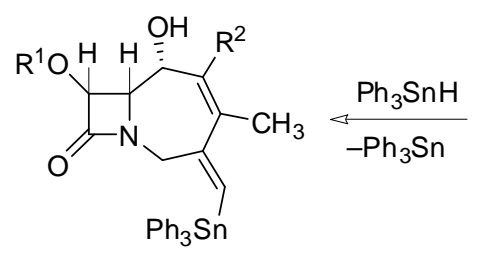

133

central adduct<smiles>[R]C(C=C)C(O)C1C([R10])C(=O)N1C/C=C\[SnH2]</smiles>

138<smiles>[R]C1=C(C)/C(=C/[SnH2])CN2C(=O)C([R20])[C@H]1C2O</smiles>

139
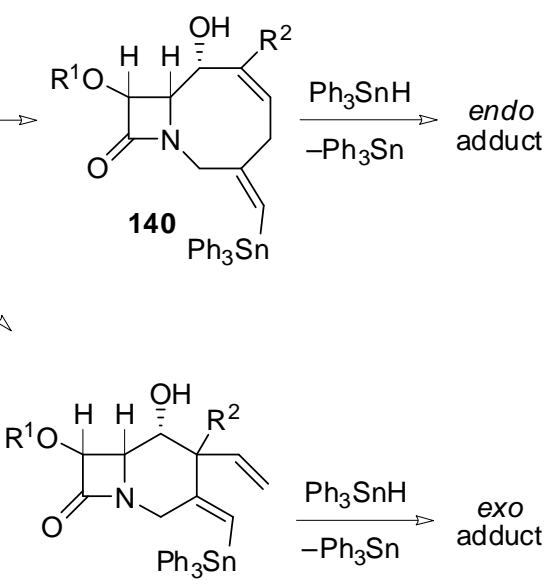

141

Scheme 47 


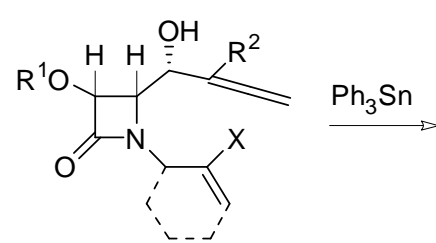

134, 136

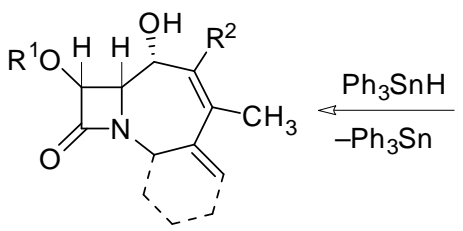

135, 137

central adduct

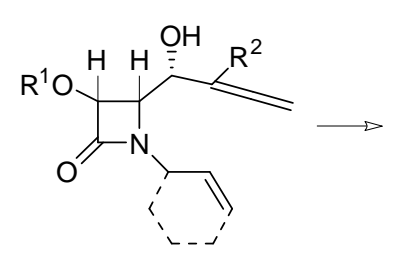

142<smiles>[R]C1=C(C)C2=CCCCC2N2C(=O)C([R9])(O)C12</smiles>

143

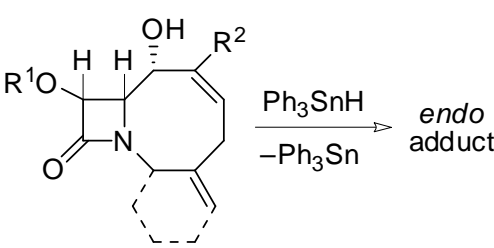

144

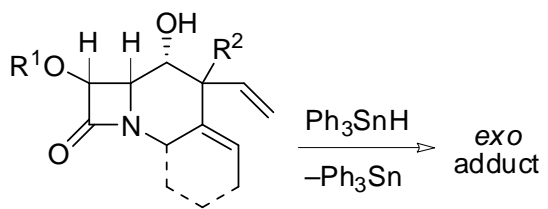

145

Scheme 48

Aryl-2-azetidinone-tethered haloarenes were used for the regiocontrolled preparation of fused tetracyclic biaryl-2-azetidinones which can be considered as $\beta$-lactam-biaryl hybrids via aryl-aryl radical cyclization [42]. Treatment of trans$\beta$-lactams 146 with tributyltin hydride and AIBN in benzene at reflux under high dilution conditions ( $215 \mathrm{~mL}$ per mmol of starting 2-azetidinone) smoothly formed the corresponding condensed tetracyclic biaryl-2-azetidinones 147 in good yields as single trans-diastereomers after chromatographic purification (Scheme 49) together with small amounts of reduced starting material.<smiles>[X]c1ccc([C@H]2C(OC(C)=O)C(=O)N2c2ccc([Y])cc2Br)cc1</smiles>

146

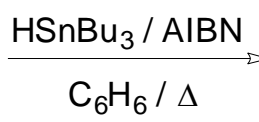

$$
\mathrm{C}_{6} \mathrm{H}_{6} / \Delta
$$<smiles>[X]c1ccc2c(c1)-c1cc([X])ccc1N1C(=O)C(OC(C)=O)[C@H]21</smiles>

$147(60-72 \%)$

$X=\mathrm{MeO}, \mathrm{H} ; \mathrm{Y}=\mathrm{H}, \mathrm{Me}$

Scheme 49

\section{3}

\section{Using Metal-Mediated Reactions}

It has been reported the ring-closing metathesis (RCM) of 1,4-bis(ene)-substituted 2-azetidinones 148, allowing synthetically rapid access to a wealth of novel, potentially biologically active, bicyclic $\beta$-lactam arrays, 149 (Scheme 50) [43]. The ring-closing metathesis runs were performed using either a molybdenum catalyst (Schrock catalyst) or a ruthenium catalyst (Grubbs' carbene), depending on the requirements of the reaction. Seven-membered ring closure to a 
homooxacephem derivative was achieved in an excellent isolated yield of $84 \%$, clearly demonstrating the synthetic utility of this method in these systems. Closure of bicyclic $\beta$-lactams with increasing ring sizes was possible, albeit progressively less successful. The eight-membered ring system was produced in 52\% yield using 5\% mol of Schrock catalys and in an improved 76\% yield using $10 \% \mathrm{~mol}$ of the molybdenum catalyst. The nine-membered fused system was isolated in only $12 \%$ yield under the same conditions but could be optimized to 23\% using $20 \%$ mol of Schrock catalyst. The ten-membered ring was produced in 3\% yield using $5 \mathrm{~mol} \%$ of the molybdenum catalyst and in $10 \%$ yield under high dilution and a higher catalyst loading.

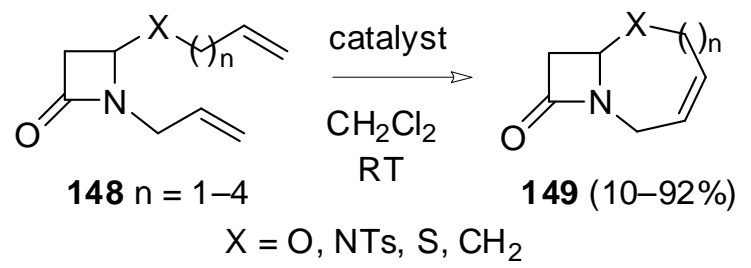

Scheme 50

While these results clearly established that polyfunctional $\beta$-lactam dienes were excellent substrates for metathesis, the reactions were not appropriate for the synthesis of bioactive $\beta$-lactam carboxylic acids. In order to find utility for this metathetic approach in the generation of novel drug candidates, a carboxylic acid motif adjacent to the lactam nitrogen was installed. The requisite framework was incorporated via Ireland-Claisen rearrangement of silyl ketene acetals derived from allyl ethers 150. The silyl ketene acetals underwent smooth rearrangement affording the corresponding carboxylic acids in excellent yields, but as inseparable 1:1 mixtures of diastereoisomers. The above carboxylic acids had only limited solubility in the normal solvents for metathesis, and were directly converted into the corresponding ethyl or p-nitrobenzyl esters 151. Treatment of monocyclic dienes $\mathbf{1 5 1}$ with Schrock or Grubbs carbenes resulted in cyclization to provide bicyclic $\beta$-lactams 152 (Scheme 51) [44].
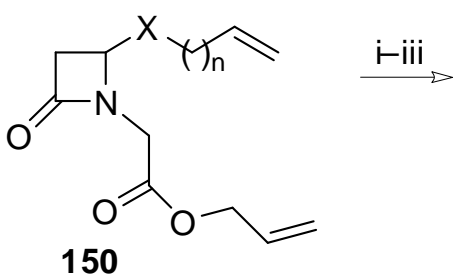

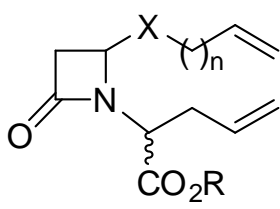

151

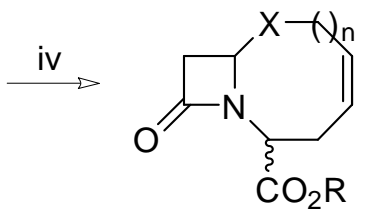

$152(50-98 \%)$

$$
\begin{aligned}
& \mathrm{X}=\mathrm{O}, \mathrm{NTs}, \mathrm{S}, \mathrm{CH}_{2} \\
& \mathrm{R}=\mathrm{PNB}, \mathrm{Et} \\
& \mathrm{n}=0-1
\end{aligned}
$$

Scheme 51 i) LiHMDS, THF; ii TMSCl, $\Delta$; iii RBr, $\mathrm{K}_{2} \mathrm{CO}_{3}$, DMF; iv catalyst, $\mathrm{CH}_{2} \mathrm{Cl}_{2}$, RT. 
The synthesis of bicyclic 2-azetidinones 154 has been accomplished by ring-closing metathesis reaction of monocyclic diene- and enyne- $\beta$-lactams. The enyne metathesis of compounds 153 afforded bicycles 154 in good yields (Scheme 52) [45].

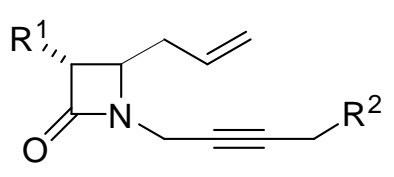

153
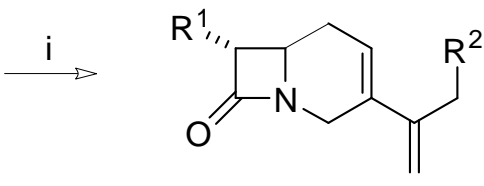

$154(72-100 \%)$

$\mathrm{R}^{1}=\mathrm{H}, \widehat{\text { OTBS }}_{\xi}^{\mathrm{S}} ; \mathrm{R}^{2}=\mathrm{H}$, OTBS

Scheme 52 i) $\left[\mathrm{Cl}_{2}\left(\mathrm{PCy}_{3}\right)_{2} \mathrm{Ru}=\mathrm{CHPh}\right], \mathrm{CH}_{2} \mathrm{Cl}_{2}, \mathrm{RT}$.

It has been reported that conveniently substituted bis- $\beta$-lactams, pyrrolidinyl- $\beta$-lactams and piperidinyl- $\beta$-lactams undergo ring-closing methatesis using Grubbs' carbene, $\mathrm{Cl}_{2}\left(\mathrm{Cy}_{3} \mathrm{P}\right)_{2} \mathrm{Ru}=\mathrm{CHPh}$, to give medium-sized rings fused to bis-2-azetidinone, pyrrolidinyl-2-azetidinone or piperidinyl-2-azetidinone systems [46]. The diolefinic cyclization precursors were obtained from optically pure 4oxoazetidine-2-carbaldehydes bearing an extra alkene tether at position 1 or 3 of the $\beta$-lactam ring via [2+2] cycloaddition of imino 2-azetidinones, $N$-metalated azometine ylide [3+2] cycloaddition and subsequent $\mathrm{N}$-acylation of the pyrrolidinyl nitrogen atom, or through aza Diels-Alder of 2-azetidinone-tethered imines. Under standard reaction conditions, the combination of cycloaddition reactions of 2-azetidinone-tethered imines with ring-closing methatesis offers an asymmetric entry to a variety of unusual fused tricyclic 2-azetidinones bearing two bridgehead nitrogen atoms.

Treatment of dienes 155, 157, and 159 with Grubbs' catalyst under smooth ring-closing metathesis conditions (5 mol\%, $\mathrm{CH}_{2} \mathrm{Cl}_{2}, 2{ }^{\circ} \mathrm{C}$ ), analogous to those described for bicyclic $\beta$-lactams, did not furnished the desired tricycles. The majority of the reaction mixture was composed of unreacted dienes. It was found that dienic substrates 155, 157, and 159 require more vigorous conditions for ring closure. Among the various solvents and conditions tested, it was found that toluene at reflux temperature gave the best yields of tricyclic- $\beta$-lactams containing medium-sized central rings. Exposure of dienes 155, 157, and 159 to the ruthenium catalyst $\mathrm{Cl}_{2}\left(\mathrm{Cy}_{3} \mathrm{P}\right)_{2} \mathrm{Ru}=\mathrm{CHPh}$ under optimized cyclization conditions ( $5 \mathrm{~mol} \%$ catalyst, $0.03 \mathrm{M}$, toluene, $110{ }^{\circ} \mathrm{C}$ ) resulted in clean formation of tricycles 156, 158, and 160 in moderate to good yields (31-69\%) (Schemes 53-55). It should be mentioned that for a successful RCM a structural condition must be satisfied in the starting dienes, namely, a relative anti-stereochemistry at the single bond connecting the two heterocyclic rings. Interestingly, in the Grubbs' 
carbene promoted reaction of compounds 159b and 159c together with the RCM products 160b and 160c $N$-deallylation products were also isolated.<smiles>C=CCN1C(=O)C(OC)C1C1C(Oc2ccccc2)C(=O)N1C=C</smiles>

$155 \mathrm{a} n=1$ $155 b \mathrm{~b}=2$<smiles>COC1C(=O)N2C/C=C\CN3C(=O)C(O)C3C12</smiles>

$156 \mathrm{a} \mathrm{n}=1(69 \%)$

$156 \mathrm{~b} \mathrm{n}=2(54 \%)$

Scheme 53 i) $\left[\mathrm{Cl}_{2}\left(\mathrm{PCy}_{3}\right)_{2} \mathrm{Ru}=\mathrm{CHPh}\right]$, toluene, reflux.

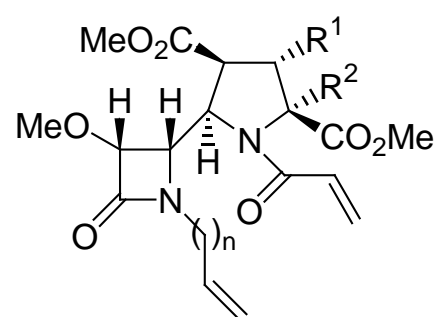

$157 a$

$157 b$

$157 \mathrm{c}$

157d

$157 e$

$157 f$

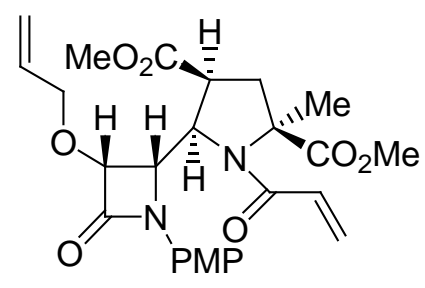

$157 g$

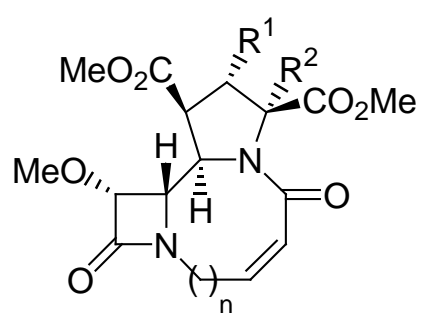

158a $R^{1}=H, R^{2}=H, n=1(62 \%)$

158b $R^{1}=H, R^{2}=M e, n=1(67 \%)$

158c $\mathrm{R}^{1}=\mathrm{CO}_{2} \mathrm{Me}, \mathrm{R}^{2}=\mathrm{Me}, \mathrm{n}=1(57 \%)$

$158 d R^{1}=H, R^{2}=H, n=2(58 \%)$

158e $R^{1}=H, R^{2}=M e, n=2(58 \%)$

158f $R^{1}=H, R^{2}=M e, n=3(35 \%)$

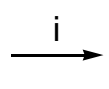

$\longrightarrow$

$158 g(35 \%)$

Scheme 54 i) $\left[\mathrm{Cl}_{2}\left(\mathrm{PCy}_{3}\right)_{2} \mathrm{Ru}=\mathrm{CHPh}\right]$, toluene, reflux.<smiles>C=CCN1CCC(=O)C[C@H]1C1C(OC)C(=O)N1[14C](=O)c1cccnc1</smiles>

$159 a$

$159 b$

$159 \mathrm{c}$

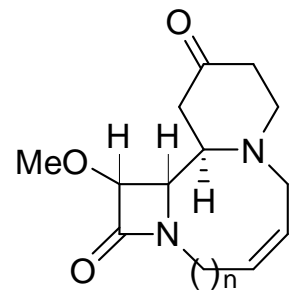

160a $\mathrm{n}=1(53 \%)$

$160 \mathrm{~b} \mathrm{n}=2(31 \%)$

$160 \mathrm{c} n=3(33 \%)$

Scheme 55 i) $\left[\mathrm{Cl}_{2}\left(\mathrm{PCy}_{3}\right)_{2} \mathrm{Ru}=\mathrm{CHPh}\right]$, toluene, reflux. 
The synthesis of tricyclic $\beta$-lactams via palladium-catalyzed cyclization of iodoaryl $\beta$-lactams using a catalyst system comprising $10 \mathrm{~mol} \% \operatorname{Pd}(\mathrm{AcO})_{2}, 20$ mol\% $\mathrm{PPh}_{3}$, and $\mathrm{Tl}_{2} \mathrm{CO}_{3}$ (2 mol) has been afforded [47]. The methallyl $\beta$-lactam 161 underwent 7-endo-trig cyclization to give a 8:1 mixture of double bonds isomers 162 and 163 (Scheme 54).<smiles>C=C(C)CN1C(=O)[C@H](N2C(=O)c3ccccc3C2=O)C1c1ccccc1I</smiles>

161

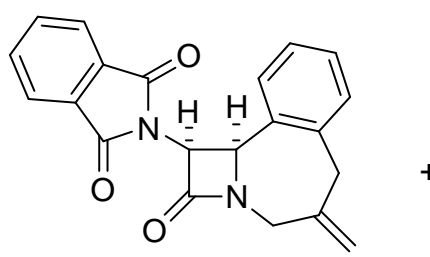

162

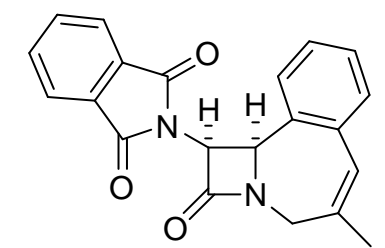

163

Scheme 56

It has been shown that combination of bromoallylation reaction and Heck cyclization is an useful methodology for the preparation of a variety of fused bicyclic $\beta$-lactams of non-conventional structure [48]. Starting from acetates 164 and using palladium acetate as the palladium source, DMF as solvent, potassium carbonate as base and triphenylphosphine the reaction occurred. The reaction conditions were further optimized and typical results for the preparation of bicyclic $\beta$-lactams 165-168 are summarized in Scheme 57.

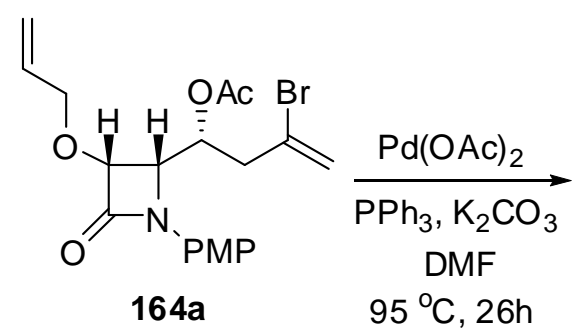<smiles>C=C(Br)/C=C/O[C@@H]1C(=O)N(P(C)(C)(C)C)[C@H]1[C@H](CC(=C)Br)OC(C)=O</smiles><smiles>C=CC[C@H]1C(=O)N(P)[C@H]1[C@H](CC(=C)Br)OC(C)=O</smiles>

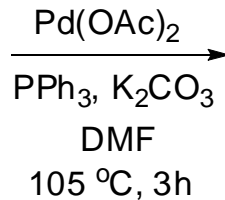

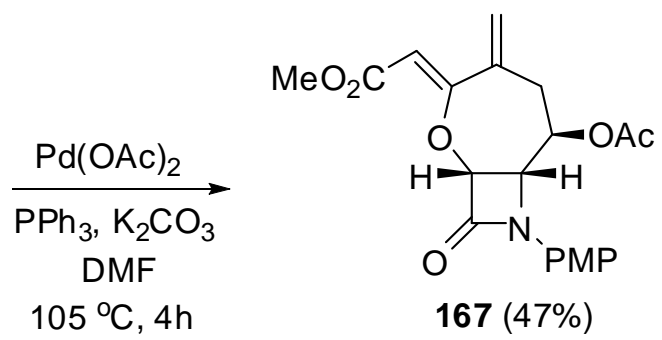<smiles>C=C1CO[C@H]2C(=O)N(P(N)P)[C@H]2[C@H](OC(C)=O)CC1=C</smiles>

$165(21 \%)$<smiles>[Y10]N1C(=O)[C@@H]2OC/C=C\C(=C)C[C@@H](OC(C)=O)[C@@H]21</smiles>

$166(27 \%)$

Scheme 57

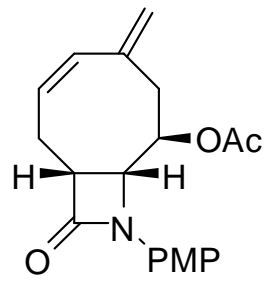

$168(60 \%)$ 
Special mention deserves the Heck reaction of acetate 164d. Substitution pattern on bromodiene 164d should direct the regiochemical outcome of the cyclization to the six-membered or seven-membered ring formation. Interestingly, we found that the reaction produced the five-membered fused bicycle 169a as the only isomer. As a result of steric congestion, the stereocontrolled construction of carbon atoms having four carbon ligands is a formidable challenge for chemical synthesis. Compound 169a is remarkable since it bears a quaternary stereocenter. Adduct 169a presumably arises from the Pd-catalyzed 5-exo cyclization of the initially formed $\alpha, \beta$-unsaturated carbonyl compound 170a. A similar reaction pattern was observed on reacting bromodienes syn-164e and anti-164e. Thus, bicyclic $\beta$-lactams 169b and 169c were also prepared through essentially the same procedure (Scheme 58).
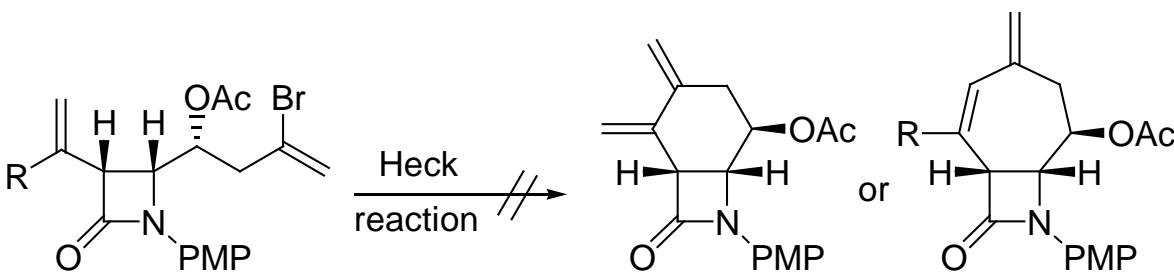

164d $\mathrm{R}=\mathrm{H}$

syn-164e $\mathrm{R}=\mathrm{Me}$

$$
\mid \begin{aligned}
& \mathrm{Pd}(\mathrm{OAc})_{2}, \mathrm{PPh}_{3} \\
& \mathrm{~K}_{2} \mathrm{CO}_{3}, \mathrm{DMF}
\end{aligned}
$$

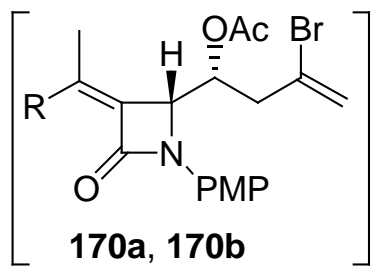

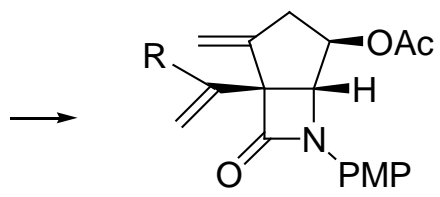

169a $\left(60 \% ; 150{ }^{\circ} \mathrm{C}, 1 \mathrm{~h}\right)$

$169 b\left(65 \% ; 105^{\circ} \mathrm{C}, 0.5 \mathrm{~h}\right)$<smiles>C=C(Br)C[C@H](OC(C)(C)C)[C@H]1[C@@H](C(=C)C)C(=O)N1[18OH]</smiles><smiles>O=C(O[Na])OCCOC(=O)OCc1ccccc1</smiles><smiles>C=C(C)C1(C(=O)O)C(=O)N([Pb])C1C(C)(C)C(C)(C)C</smiles>

Scheme 58

The above hypothesis was probed showing that the intermediate $\mathbf{1 7 0}$ could be obtained from 164, and that this new bromodiene does give the corresponding fused $\beta$-lactam 169 under Heck conditions. This mechanistically informative result was provided by the treatment of the bromohomoallylic acetate 164d with potassium carbonate in acetonitrile to give a separable mixture of isomeric bromodienes E-170a and Z-170a, which under palladium catalysis afforded the 
expected bicycle 169a. The two-step synthesis of compound 169a from diene 164d is depicted in Scheme 59.
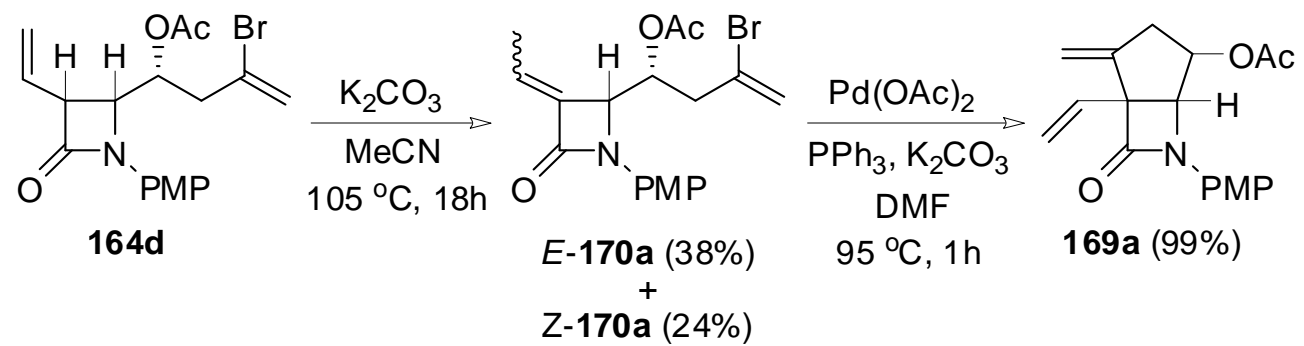

Z-170a (24\%)

\section{Scheme 59}

The allene moiety represents a versatile and useful building block in organic synthesis. However, selectivity problems are significant. Intramolecularization of the reactions, usually by placing the group at such distance that five- or six-membered rings are formed, automatically should solve the positional selectivity problems because larger rings are unfavored. The less exploited allenic variant of the Pauson-Khand type cycloaddition was explored in allenynes 171 [49]. Substitution patterns on allenynes 171 were selected in order to direct the regiochemical outcome of the cycloaddition to the six-membered central ring formation because the intramolecular variant of the Pauson-Khand reaction has been largely restricted to the construction of bicyclo[3.3.0]octenones and bicyclo[4.3.0]nonenones. However, it was found that the $[2+2+1]$ cycloaddition produced tricycles 173 bearing a central seven-membered ring as the only isomer. Cycloadducts $\mathbf{1 7 3}$ presumably arises from the isomerization of the initially formed adducts 172 (Scheme 60). Conjugation of the dienone moiety with the lone pair of the nitrogen atom is believed to promote the formation of compounds 173.

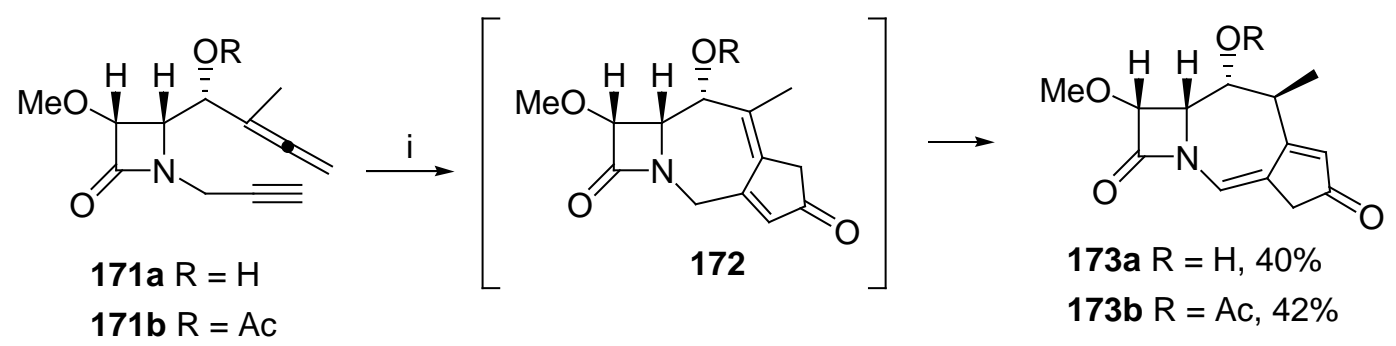

Scheme 60 i) $\mathrm{Co}_{2}(\mathrm{CO})_{8}, \mathrm{Me}_{3} \mathrm{NO}, \mathrm{CH}_{2} \mathrm{Cl}_{2}, \mathrm{RT}$.

The 1,2-functionalization of the allene moiety in 2-azetidinone-tethered allenynol derivatives has also been explored [49]. Carbamate 174 was selected as the starting material for the palladium(II)-catalyzed reaction. The above carbamate was prepared from the $\alpha$-allenic alcohol 171a by treatment with tosyl isocyanate. Reaction of compound $\mathbf{1 7 4}$ was carried out at room temperature in acetonitrile in the presence of $10 \mathrm{~mol} \%$ of $\mathrm{Pd}(\mathrm{OAc})_{2}, 5$ equiv of $\mathrm{LiBr}, 2$ equiv of $\mathrm{Cu}(\mathrm{OAc})_{2}$ and 
1.2 equiv of $\mathrm{K}_{2} \mathrm{CO}_{3}$ under an atmospheric pressure of oxygen. The ${ }^{1} \mathrm{H}-\mathrm{NMR}$ spectrum of the crude material displayed neither signal corresponding to the allene or alkyne moieties. To our delight, the resulting product was identified after purification as the tricycle 175 (Scheme 61). Compound 175 was isolated in moderate yield as the only isomer, indicating that both the regio- and stereoselectivity are extremely high.
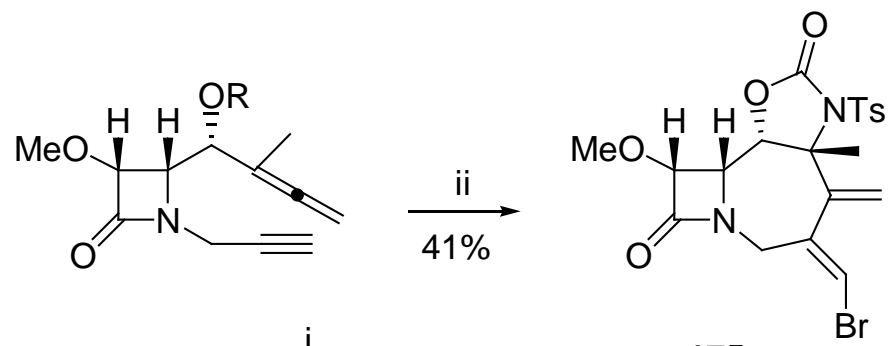

171a, $\mathrm{R}=\mathrm{H} \frac{\mathrm{i}}{94 \%}$
174, $\mathrm{R}=$ OCONHTS

175

Scheme 61 i) TsNCO, THF, RT; ii Pd(OAc) 10 mol\%, $\mathrm{LiBr}, \mathrm{Cu}(\mathrm{OAc})_{2}, \mathrm{~K}_{2} \mathrm{CO}_{3}, \mathrm{O}_{2}$, acetonitrile, RT.

The formation of compound $\mathbf{1 7 5}$ could be rationalized in terms of an unprecedented domino allene amidation/intramolecular Heck-type reaction. Compound 176 must be the not isolable intermediate. A likely mechanism for 176 should involve a ( $\pi$-allyl)palladium intermediate. The allene-palladium complex $\mathbf{1 7 7}$ is formed initially and suffers a nucleophilic attack by the bromide to produce a $\sigma$-allylpalladium intermediate, which rapidly equilibrates to the corresponding ( $\pi$-allyl)palladium intermediate 178. Then, an intramolecular amidation reaction on the ( $\pi$-allyl)palladium complex must account for intermediate 176 formation. Compound 176 evolves to tricycle 175 via a Heck-type-coupling reaction. The alkenylpalladium intermediate $\mathbf{1 7 9}$, generated in the 7-exo-dig cyclization of bromoenyne 176, was trapped by the bromide anion to yield the fused tricycle $\mathbf{1 7 5}$ (Scheme 62). Thus, the same catalytic system is able to promote two different, but sequential catalytic cycles. 


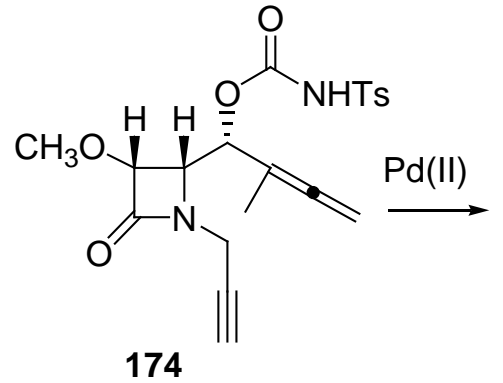

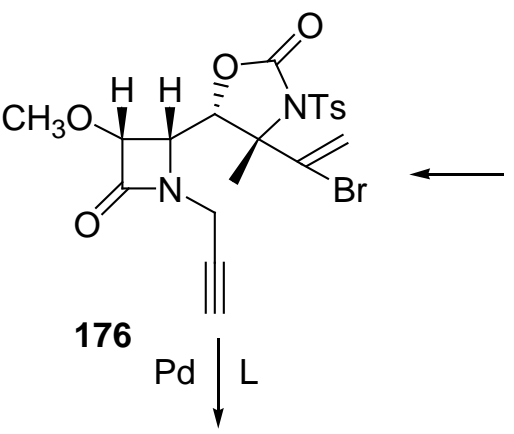

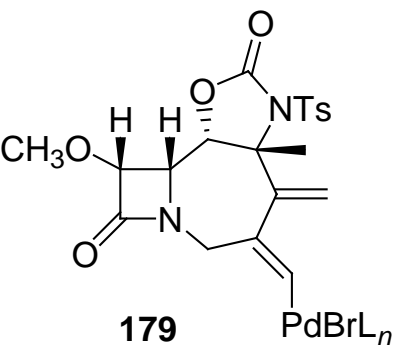<smiles>C=C1/C(=C/Br)CN2C(=O)[C@H](O)[C@H]2[C@H]2OC(=O)[NH2+][C@]12S</smiles>

Scheme 62

The reactivity of the allenynol moiety itself under these cascade conditions was also explored [49]. Interestingly, treatment of allenynols 171a, 180 and 181 under the above palladium-catalyzed domino reaction conditions afforded the bridged medium-sized ring tricycles $\mathbf{1 8 2}$ as single isomers albeit in moderate yields (Scheme 63). Although complete conversion was observed by TLC and ${ }^{1} \mathrm{H}$ NMR analysis of the crude reaction mixtures, the high polarity of adducts $\mathbf{1 8 2}$ may be responsible for the modest isolated yields. Compounds $\mathbf{1 8 2}$ are remarkable since they possess an unusual pyramidalized bridgehead structure. An analogous cascade process to compound $\mathbf{1 7 5}$ formation seems to be taking part in this transformation. However, a dramatic change in the regioselectivity of the nucleophilic insertion into the ( $\pi$-allyl)palladium intermediate 183 was observed when the bridged dihydrofurans were formed as the exclusive products. The thermochemically more stable five-membered intermediate 184 must be involved in the reaction rather than the corresponding regioisomeric oxirane. Taking into account the precedent explanation for fused compound $\mathbf{1 7 5}$ formation, Scheme 64 outlines a mechanistic hypothesis for the achievement of bridged compounds $\mathbf{1 8 2}$. 


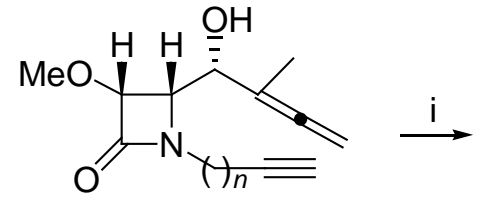

$171 \mathrm{a} n=1$

$180 \mathrm{n}=2$

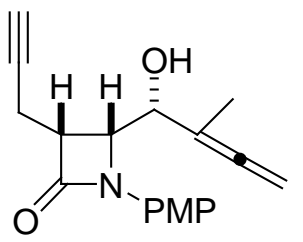

181
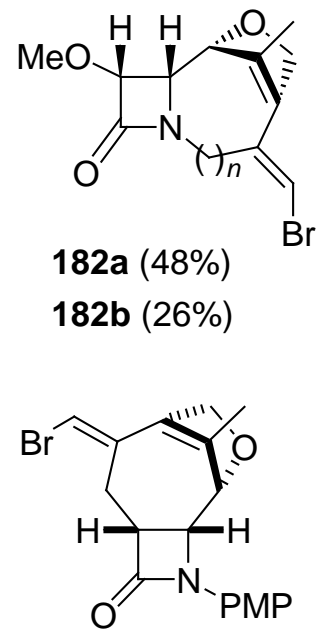

182c (52\%)

Scheme 63 i) $\mathrm{Pd}(\mathrm{OAc})_{2} 10$ mol\%, $\mathrm{LiBr}, \mathrm{Cu}(\mathrm{OAc})_{2}, \mathrm{~K}_{2} \mathrm{CO}_{3}, \mathrm{O}_{2}$, acetonitrile, RT; ii $\mathrm{Pd}(\mathrm{OAc})_{2} 10$ mol\%, $\mathrm{LiBr}, \mathrm{Cu}(\mathrm{OAc})_{2}, \mathrm{~K}_{2} \mathrm{CO}_{3}, \mathrm{O}_{2}$, acetonitrile, reflux.
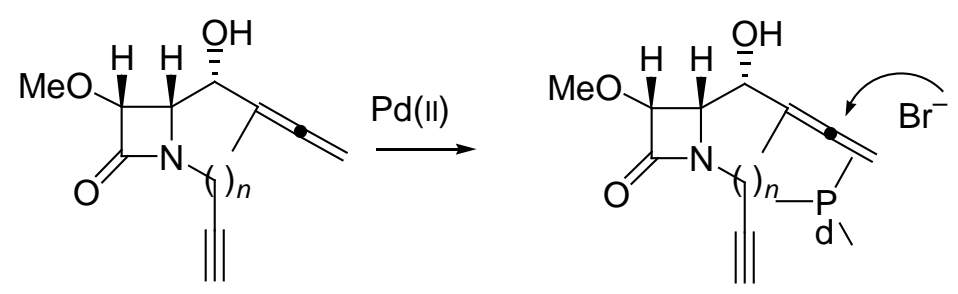

171,180<smiles>C#CCN1C(=O)[C@H](OC)[C@H]1[C@H]1OCC(Br)=C1C</smiles>

184

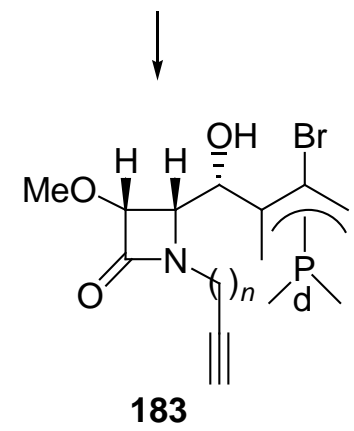

$P d \downarrow$
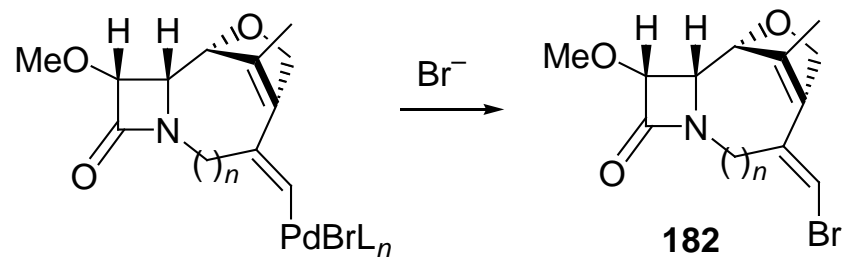

\section{Scheme 64}

$\gamma$-Allenol 185a was used as initial substrate in a screen to identify regioselective hydroalkoxylation catalysts for the preparation of bicyclic $\beta$ lactams [50]. Thus, $\left[\mathrm{PtCl}_{2}\left(\mathrm{CH}_{2}=\mathrm{CH}_{2}\right)\right]_{2}$ and $\mathrm{AgNO}_{3}$ afforded rather low yield or disappointing diastereomeric mixture of bicycle 186a. Although $\mathrm{AgNO}_{3}$ was less diastereoselective than $\left[\mathrm{PtCl}_{2}\left(\mathrm{CH}_{2}=\mathrm{CH}_{2}\right)\right]_{2}(60: 40$ vs 100:0), it was a more 
efficient catalyst affording adduct 186a in reasonable yield (54\% vs 12\%). Gratifyingly, it was found that $\mathrm{Au}^{\mathrm{I}}$ or $\mathrm{Au}^{\mathrm{III}}$ salts were effective as 5-exo selective hydroalkoxylation catalysts. $\mathrm{AuCl}_{3}$ was selected as catalyst of choice because of its superior performance. No diastereo- or regioisomeric products were detected, giving exclusively the fused five-membered oxacycles 186 (Scheme 65). Tetrahydrofuran-fused 2-azetidinones $\mathbf{1 8 6}$ are remarkable since they bear a quaternary stereocenter.

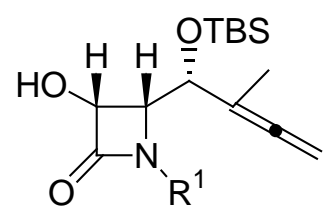

$185 a R^{1}=B n$ $185 b \mathrm{R}^{1}=$ allyl
$5 \mathrm{~mol} \% \mathrm{AuCl}_{3}$, $\mathrm{CH}_{2} \mathrm{Cl}_{2}$, RT

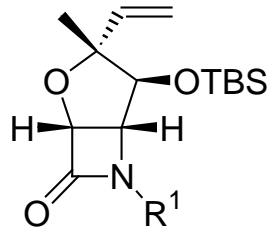

186a $\mathrm{R}^{1}=\mathrm{Bn}(57 \%)$ 186b $\mathrm{R}^{1}=$ allyl (58\%)

Scheme 65

Having found a solution for the 5-exo selective hydroalkoxylation, it was next examined the more intricate heterocyclizative problem associated with tuning the regioselectivity of $\gamma$-allenols. Worthy of note, the $\mathrm{Pd}^{\mathrm{II}}$-catalyzed cyclizative coupling reaction of $\gamma$-allenols $\mathbf{1 8 5 a}$ and $\mathbf{1 8 5 b}$ with allyl halides gave impressive yields (up to 94\%) of the desired seven-membered adducts 187a-d (Scheme 66), resulting from a 7-endo oxycyclization [51].

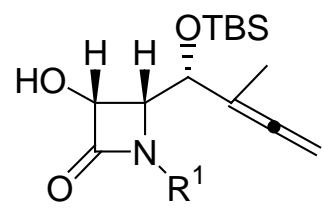

185a $R^{1}=B n$

$185 a R^{1}=B n$

$185 a R^{1}=B n$

$185 \mathrm{~b} \mathrm{R}^{1}=$ allyl

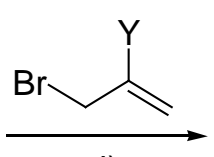

i)

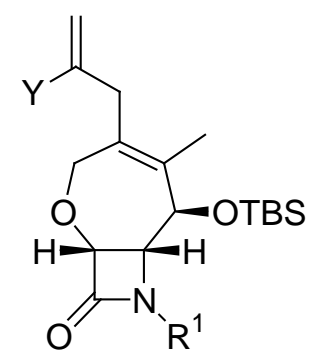

187a $\mathrm{R}^{1}=\mathrm{Bn}, \mathrm{Y}=\mathrm{H}(83 \%)$

187b $R^{1}=B n, Y=M e(67 \%)$

187c $\mathrm{R}^{1}=\mathrm{Bn}, \mathrm{Y}=\mathrm{Br}(63 \%)$

187d $R^{1}=$ allyl, $Y=H(94 \%)$

Scheme 66 i) 5 mol \% $\mathrm{PdCl}_{2}$, DMF, RT.

When MOM protected $\gamma$-allenol derivatives 188a and $\mathbf{1 8 8 b}$ were used as starting materials for the $\mathrm{Au}^{\mathrm{III}}$-catalyzed cycloisomerization, the 5-exo mode was completely reverted to a 7-endo cyclization to afford bicycles 189 in fair yields (Scheme 67). It seems that the reactivity in this type of $\mathrm{Au}^{\mathrm{III}}$-catalyzed reactions is determined by the presence or absence of a methoxymethyl protecting group at the $\gamma$-allenol oxygen atom, as the free $\gamma$-allenols 185a and 185b gave 5-exo hydroalkoxylation, while MOM protected $\gamma$-allenol derivatives 188a and $\mathbf{1 8 8 b}$ 
exclusively underwent a 7-endo oxycyclization [51]. No other isomers or side products were detected.

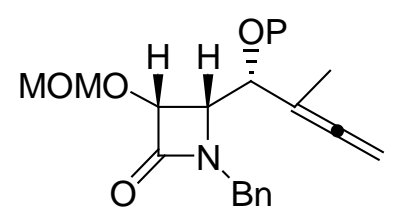

188a $\mathrm{P}=4-\mathrm{BrC}_{6} \mathrm{H}_{4} \mathrm{CO}$

188b $P=P M P C O$
$5 \mathrm{~mol} \% \mathrm{AuCl}_{3}$, $\mathrm{CH}_{2} \mathrm{Cl}_{2}$, RT

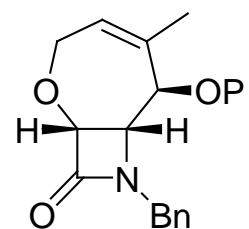

189a $\mathrm{P}=4-\mathrm{BrC}_{6} \mathrm{H}_{4} \mathrm{CO}(58 \%)$

189b $\mathrm{P}=\mathrm{PMPCO}(45 \%)$

Scheme 67

The pathway proposed in Scheme 68 looks valid for the formation of products 189. It could be presumed that the initially formed allenegold complex 190 undergoes an intramolecular attack (7-endo versus 5-exo oxyauration) by the (methoxymethyl)oxy group, giving rise no to species 191 but to the tetrahydrooxepine intermediate 192. Protonolysis of the carbon-gold bond linked to an elimination of methoxymethanol would then liberate the bicycle 189 with concomitant regeneration of the $\mathrm{Au}^{\mathrm{III}}$ species. Probably, the proton in the last step of the catalysis cycle comes from the trace amount of water present in the solvent or in the catalyst. In order to confirm the mechanistic proposal of Scheme 68, labeling studies with deuterium oxide were performed. Thus, the addition of two equivalents of $\mathrm{D}_{2} \mathrm{O}$ to the solution of MOM protected $\gamma$-allenol $\mathbf{1 8 8 \mathbf { b }}$ and $\mathrm{AuCl}_{3}$ in dichloromethane caused the disappearance of the peak at $6.35 \mathrm{ppm}$, which is the signal of the proton $\mathrm{H} 4$, on the 2-oxa-8-azabicyclo[5.2.0]non-4-en-9-one 189b. The fact that the $\mathrm{AuCl}_{3}$-catalyzed conversion of allenol $\mathbf{1 8 8 b}$ into bicycle $\mathbf{1 8 9 b}$ in the presence of 2 equiv of $\mathrm{D}_{2} \mathrm{O}$ afforded 4-[D]-189b as judge by ${ }^{1} \mathrm{H}$ NMR spectroscopy, suggests that a deuterolysis of the carbon-gold in species 192 has occurred. It may be inferred that different steric effects in the organometallic species 191 and 192 may be responsible for the different reactivity preference, stabilizing one of the intermediates rather than the other. In the presence of MOM group, 5-exo cyclization falters. Probably, 5-exo oxyauration via 191 is restricted by the steric hindrance between the (methoxymethyl)oxy group and the substituents at the quaternary stereocenter [52]. 


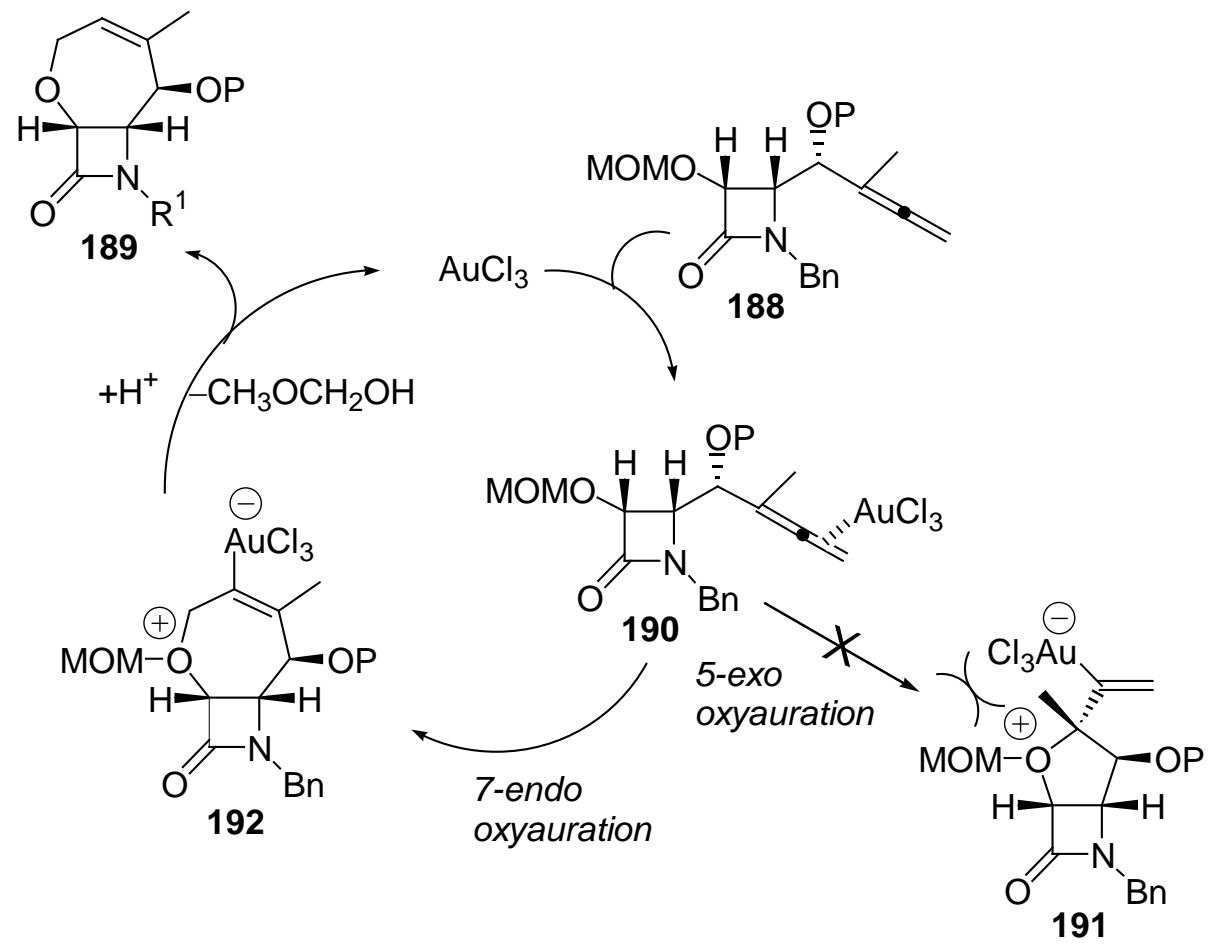

\section{Scheme 68}

A synthetic route to $\beta$-lactam-fused enediynes by intramolecular Kinugasa reaction has been successfully developed. The method has widened the scope of Kinugasa reaction in the synthesis of sensitive systems like tricycle 193 (Scheme 69) [53].

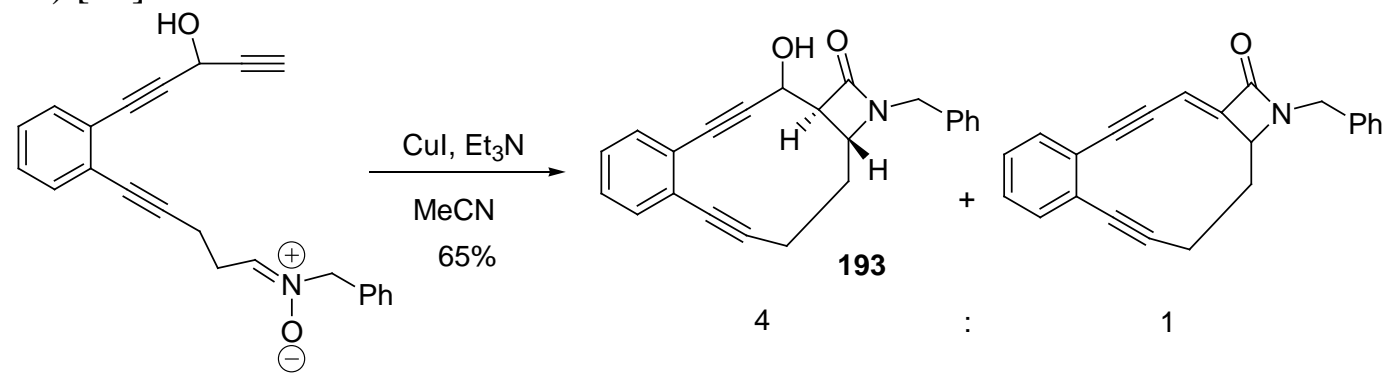

Scheme 69

\section{4}

\section{Using Cyclization Reactions}

A wide range of $\alpha, \beta$-unsaturated aldehydes, including 3-alkyl derivatives, undergo $\mathrm{N}$-heterocyclic carbene (NHC)-catalyzed annulations with $\mathrm{N}$-sulfonyl ketimines under mild conditions to provide bicyclo[3.2.0]lactams 194 with outstanding diastereo- and enantioselectivity (Scheme 70) [54]. This concise route to $\beta$-lactams established four new chiral centers in a single operation. Although this process could occur via the intermediacy of a catalytically generated 
homoenolate equivalent, the stereochemical outcome supports a tandem or concerted aza-benzoin/oxy-Cope reaction as the key bond-forming step.

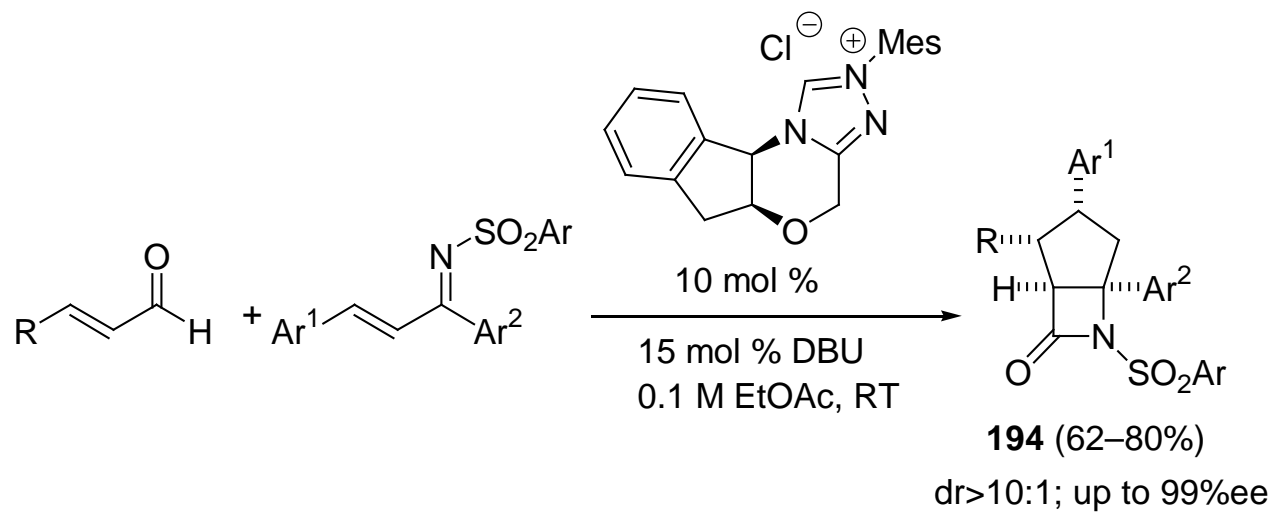

Scheme 70

Two different stereocontrolled accesses to new 4-hydroxypipecolic acid analogues with a bicyclic $\beta$-lactam structure have been developed by using intramolecular reductive amination or allenic hydroamination reactions in 2azetidinone-tethered azides [55]. When it was tried to reduce azide 195 using the triphenylphosphine method, a complex reaction mixture was observed. Fortunately, it was found that 2-azetidinone-tethered azidoallenic acetate 196 when treated at room temperature with triphenyltin hydride in benzene solution, gave in a totally regioselective fashion the bicyclic 4-hydroxypipecolic acid analogue 197 through a 6-exo-dig aminocyclization with concomitant acetate cleavage (Scheme 71). Exposure of aldol adduct 198 to the $\mathrm{Ph}_{3} \mathrm{P}-\mathrm{H}_{2} \mathrm{O}$ reductive system did afford a mixture of highly polar compounds, which could not be characterized. The hydrogenation reaction of azidoaldol 198 performed in the presence of $\mathrm{Boc}_{2} \mathrm{O}$ revealed through ${ }^{1} \mathrm{H}$ NMR monitoring the formation of little cyclization product, while the major components in the mixture were sideproducts. Then, it was decided to carry out reduction of the azide and in situ cyclization and protection of the resultant secondary amine as the benzylcarbamate. Interestingly, exposure of compound 198 to $\mathrm{H}_{2}$ (1 atm) in ethyl acetate at room temperature in the presence of a catalytic amount of Pd ( $10 \%$ on C) followed by the addition of benzyl chloroformate, provided the 4hydroxypipecolic acid analogue $\mathbf{1 9 9}$ with a bicyclic $\beta$-lactam structure (Scheme 72). 


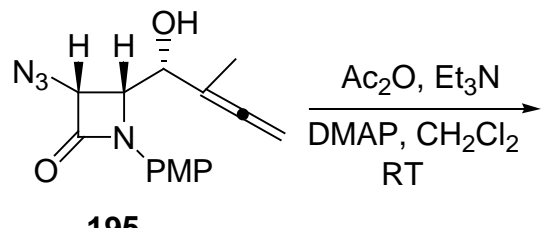

195

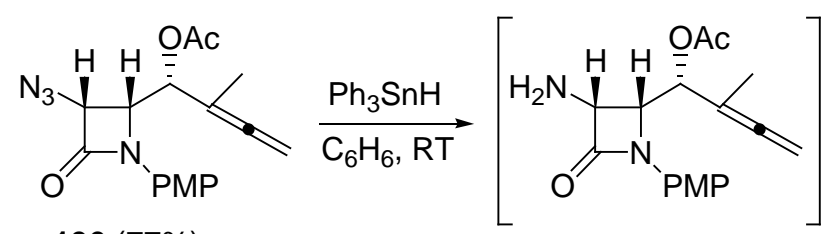

$196(77 \%)$

6-exo-dig cyclization 1,3-H shift<smiles>CC1=C(C)[C@H](O)[C@@H]2[C@H](N1)C(=O)N2P</smiles><smiles>CC(=O)O[C@H]1C(C)=C(C)[C@H]2C(=O)N(P)[C@@H]2[C@H]1C</smiles>

$197(53 \%)$

Scheme 71

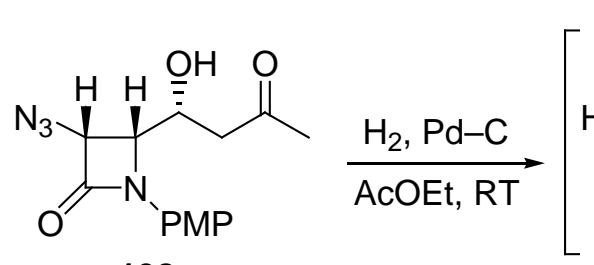

198

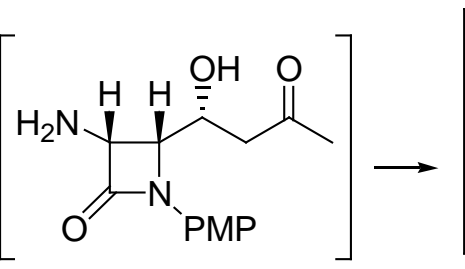

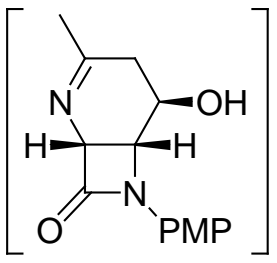

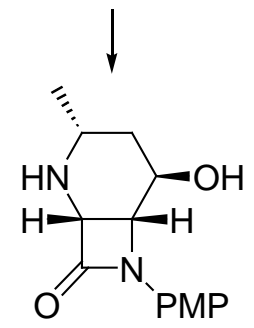

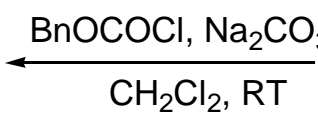

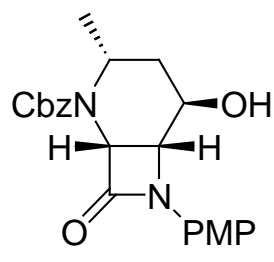

$199(49 \%)$

\section{Scheme 72}

A convenient approach to synthesize novel selenium- $\beta$-lactams, namely 3selena-1-dethiacephems 200, was accomplished via the regioselective iodocyclization reaction (Scheme 73) [56]. The key starting materials, alkyneselenoureas 201, for this approach were readily prepared by the $N$-alkylation reaction of the corresponding previously known propargyl-azetidinones with a wide variety of isoselenocyanates under basic conditions. First, it was examined the reaction of $\beta$-alkyne-selenourea 201a $\left(\mathrm{R}^{2}=4-\mathrm{ClC}_{6} \mathrm{H}_{4}\right)$ with 1.05 equiv of iodine or NIS in THF at room temperature. It was found that the reaction was highly dependent on the type of electrophile used. With NIS, it was obtained the desired 3-selena-1-dethiacephem 200a $\left(\mathrm{R}^{1}=\mathrm{H}, \mathrm{R}^{2}=4-\mathrm{ClC}_{6} \mathrm{H}\right)$ along with 3-aza4-selenoxo-1-dethiacephem and 3-aza-4-oxo-1-dethiacephem. The 3-aza-4-oxo-1dethiacephem was probably formed by the decomposition of 3-aza-4-selenoxo-1dethiacephem. However, when the reaction was carried out using 1.05 equiv of 
iodine, the desired product 200a was exclusively produced in good isolated yield (84\%) with only a trace amount of byproducts (as indicated by TLC). To improve the yield of cyclization, different reaction conditions were then screened. $\mathrm{CH}_{2} \mathrm{Cl}_{2}$ was found to be the best solvent for the cyclization reaction. Furthermore, the reaction was heavily influenced by the amount of iodine added, and the best result was obtained when 1.25 equiv of iodine was used (92\% yield). On the basis of the above results, the iodocyclization of other alkyne-selenoureas 201 with 1.25 equiv of iodine was conducted in $\mathrm{CH}_{2} \mathrm{Cl}_{2}$ at room temperature. A variety of 3-selena-1dethiacephems $\mathbf{2 0 0}$ were obtained in good to excellent yields. The nature of the $\mathrm{R}^{2}$ group on the selenourea had very little effect on the reaction rate or product yields. Aryl-substituted selenoureas gave slightly higher yield than alkylsubstituted selenoureas. The aryl substitution at alkynes was also well accommodated and afforded the cyclized products in excellent yields. The reaction shows high regioselectivity for six-membered ring selenacephems 200. Seven-membered ring products were never detected under these reaction conditions.

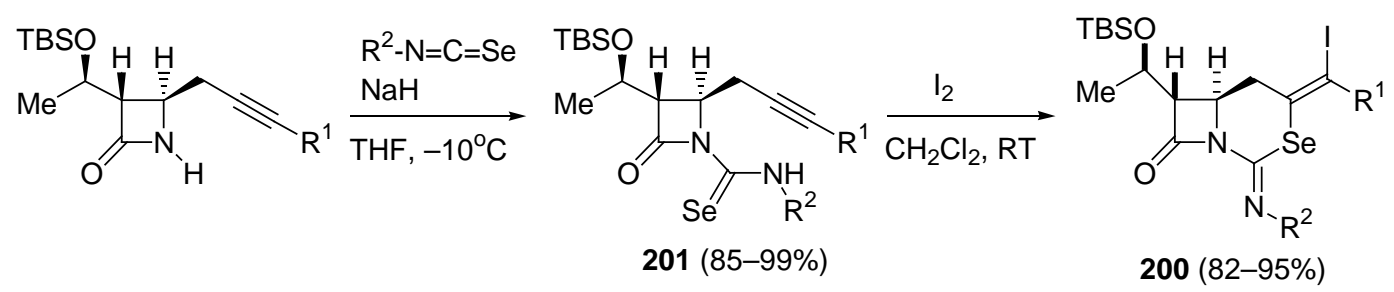

Scheme 73

\section{4}

\section{Conclusion}

The synthesis of spirocyclic and fused unusual $\beta$-lactam derivatives has been discussed. The 2-azetidinone skeleton has been extensively used as a template on which to build the carbo(hetero)cyclic structure joined to the four-membered ring, using the chirality and functionalization of the $\beta$-lactam ring as a stereocontrolling element. In many cases the compounds described in this chapter were included because of an interesting synthesis or structure, although limited biological data were found.

\section{5}

\section{References}

1. (a) Singh GS (2004) Mini-Rev. Med. Chem. 4: 69; (b) Singh GS (2004) Mini-Rev. Med. Chem. 4: 93; (c) Niccolai D, Tarsi L., Thomas R. J. (1997) Chem Commun: 2333; (d) Southgate R. (1994) Contemp Org Synth 1:417; (e) Southgate R, Branch C, Coulton S, Hunt E (1993) Recent Progress 
in the Chemical Synthesis of Antibiotics and Related Microbial Products, Lukacs G Ed., Springer: Berlin, 2:621; (f) Page I Ed. (1992) The Chemistry of $\beta$-Lactams, Chapman and Hall: London; (g) Morin RB, Gorman M Ed (1982) Chemistry and Biology of $\beta$-Lactam Antibiotics, Academic: New York.

2. (a) Cabri W, Di Fabio R (2000) Sanfetrinems From Bench to Market: The Evolution of Chemical Synthesis, Oxford University Press, Oxford, 72; (b) Kanno O, Kawamoto I (2000) Tetrahedron 56: 5639; (b) Hanessian S, Reddy B (1999) Tetrahedron 55: 3427; (c) Biondi S, Pecunioso A, Busi F, Contini SA, Donati D, Maffeis M, Pizzi DA, Rossi L, Rossi T, Sabbatine FM, (2000) Tetrahedron 56:5649; (d) Ghiron C, Rossi T The Chemistry of Trinems in Targets in Heterocyclic SystemsChemistry and Properties, Attanasi OA, Spinelli D. Eds. (1997) Societa Chimica Italiana: Rome, 1:161. (e) Ngo J, Castañer J (1996) Drugs of the Future 21:1238.

3. Brown AG, Butterworth D, Cole M, Hanscomb G, Hood JD, Reading C (1976) J Antibiot 29:668.

4. Some of the more notable advances concern the development of mechanism-based serine protease inhibitors of elastase, cytomegalovirus protease, thrombin, prostate specific antigen, and cell metastasis and as inhibitors of acyl-CoA cholesterol acyl transferase. (a) Veinberg G, Vorona M, Shestakova I, Kanepe I, Lukevics E (2003) Curr Med Chem 10:1741; (b) Hogan PC, Corey EJ (2005) J Am Chem Soc 127:15386; (c) Clader JW (2004) J Med Chem 47:1; (d) Kvaerno L, Ritter T, Werder M, Hauser H, Carreira EM (2004) Ang Chem Int Ed 43:4653; (e) Burnett DA (2004) Curr Med Chem 11:1873; (f) Page MI, Laws AP (2000) Tetrahedron 56:5631; (g) Haley TM, Angier SJ, Borthwick AD, Singh R, Micetich RG (2000) Drugs 3:512.

5. It has been reported that $\beta$-lactams act to modulate the expression of glutamate neurotransmitter transporters via gene activation. Rothstein JD, Patel S, Regan MR, Haenggeli C, Huang YH, Bergles DE, Jin L, Hoberg MD, Vidensky S, Chung DS, Toan SV, Bruijn LI, Su Zz, Gupta P, Fisher PB (2005) Nature 433:73.

6. (a) Macías A, Morán Ramallal A, Alonso E, del Pozo C, González J. (2006) J Org Chem 71:7721; (b) Bittermann H, Gmeiner P. (2006) J Org Chem 71: 97; (c) Bittermann H, Böckler F, Einsiedel J, Gmeiner P (2006) Chem Eur J 12:6315; (d) Alonso E, López-Ortiz F, del Pozo C, Peralta E, Macías A, González J. (2001) J Org Chem 66:6333.

7. For their evaluation as cholesterol absorption inhibitors, see: (a) Kambara T, Tomioka K (1999) J Org Chem 64:9282. For their evaluation as inhibitors of poliovirus and rhinovirus 3C-proteinases, see: (b) Skiles JW, McNeil D (1990) Tetrahedron Lett 31:7277.

8. (a) Macías A, Alonso E, del Pozo C, Venturini A, González J (2004) J Org Chem 69:7004; (b) Macías A, Alonso E, del Pozo C, González J (2004) Tetrahedron Lett 45:4657; (c) Alonso E, del Pozo C, González J (2002) Synlett 69; (d) Dolle RE, Li CS, Novelli R, Kruse LI, Eggleston D (1992) J Org Chem 57:128.

9. (a) Baran PS, Shenvi RA (2006) J Am Chem Soc 128:14028; (b) Sun C, Lin X, Weinreb SM (2006) J Org Chem 71:3159; (c) Baran PS, Shenvi RA, Mitsos CA (2005) Ang Chem Int Ed 44:3714; (d) Nishikawa T, Kajii S, Isobe M (2004) Synlett 2025; (e) Pinder JL, Weinreb SM (2003) Tetrahedron Lett 44:4141. Synthetic studies and biosynthetic speculation inspired by an unexpected reaction on the marine alkaloid chartelline $C$ have been described: (f) Kajii S, Nishikawa T, Isobe M (2008) Chem Commun 3121.

10. (a) Alcaide B, Almendros P, Aragoncillo, C (2007) Chem Rev 107:4437; (b) Alcaide B, Almendros P (2004) Curr Med Chem 11:1921; (c) Deshmukh ARAS, Bhawal BM, Krishnaswamy D, Govande VV, Shinkre BA, Jayanthi A (2004) Curr Med Chem 11:1889; (d) Alcaide B, Almendros P (2002) Synlett 381; (e) Palomo C, Aizpurua JM, Ganboa I, Oiarbide M (2001) Synlett 1813; (f) Alcaide B, Almendros P (2001) Chem Soc Rev 30:226; (g) Palomo C, Aizpurua JM, Ganboa I, Oiarbide M 
(1999) Amino-acids 16:321; (h) Ojima I, Delaloge F (1997) Chem So Rev 26:377; (i) Manhas MS. Wagle DR, Chiang J, Bose AK (1988) Heterocycles 27:1755.

11. Alonso E, del Pozo C, González J (2002) J Chem Soc Perkin Trans 1, 571.

12. del Pozo C, Macías A, López-Ortiz F, Maestro MA, Alonso E, González J (2004) Eur J Org Chem 535.

13. Arjona O, Murcia MC, Plumet J (2002) Tetrahedron Lett 34:6405.

14. Anklam S, Liebscher J (1998) Tetrahedron 54:6369.

15. (a) Nishikawa T, Kajii S, Isobe M (2004) Chemistry Lett 33:440; (b) Nishikawa T, Kajii S, Isobe M (2004) Synlett 2025.

16. Chowdari NS, Suri JT, Barbas III CF (2004) Org Lett 6:2507.

17. Clayden J, Hamilton SD, Mohammed RT (2005) Org Lett 7:3673.

18. Zanobini A, Gensini M, Magull J, Vidović D, Kozhushkov SI, Brandi A, de Meijere A (2004) Eur J Org Chem 4158.

19. Zanobini A, Brandi A, de Meijere A (2006) Eur J Org Chem 1251.

20. Alcaide B, Almendros P, Luna A, Torres MR (2008) Org Biomol Chem 6:1635.

21. Simone MI, Edwards AA, Tranter GE, Fleet GWJ (2008) Tetrahedron: Asymmetry 19:2887.

22. Alcaide B, Almendros P, Martínez del Campo T, Rodríguez-Acebes R (2004) Tetrahedron Lett 45:6429.

23. Alcaide B, Almendros P, Martínez del Campo T, Rodríguez-Acebes R (2007) Adv. Synth. Catal. 349:749.

24. Alcaide B, Almendros P, Rodríguez-Acebes R (2005) Chem Eur J 11:5708.

25. Alcaide B, Almendros P, Martínez del Campo T, Carrascosa R (2008) Chem Asian J 3:1140.

26. Alcaide B, Pardo C, Rodríguez-Ranera C, Rodríguez-Vicente A (2001) Org Lett 3:4205.

27. Alcaide B, de Murga RM, Pardo C, Rodríguez-Ranera C (2004) Tetrahedron Lett 45:7255.

28. (a) Desroy N, Robert-Peillard F, Toueg J, Duboc R, Hénaut C, Rager MN, Savignac M, Genêt JP (2004) Eur J Org Chem 4840; (b) Desroy N, Robert-Peillard F, Toueg J, Hénaut C, Duboc R, Rager MN, Savignac M, Genêt JP (2004) Synthesis 2665; (c) Duboc R, Hénaut C, Savignac M, Genêt JP, Bhatnagar N (2001) Tetrahedron Lett 42:2461.

29. (a) Alcaide B, Almendros P (1999) Tetrahedron Lett 40:1015; (b) Alcaide B, Almendros P, Salgado NR (2000) J Org Chem 65:3310.

30. Alcaide B, Almendros P, Pardo C, Rodríguez-Ranera C, Rodríguez-Vicente A (2003) J Org Chem 68:3106.

31. (a) Alcaide B, Almendros P, Aragoncillo C, Redondo MC (2005) Eur J Org Chem 98; (b) Alcaide B, Almendros P, Aragoncillo C, Redondo MC (2002) Chem Commun 1472.

32. Alcaide B, Almendros P, Aragoncillo C, Redondo MC, Torres MR (2006) Chem Eur J 12:1539.

33. (a) Alcaide B, Sáez E (2005) Eur J Org Chem 1680; (b) Alcaide B, Alonso JM, Aly MF, Sáez E, Martínez-Alcázar MP, Hernández-Cano F (1999) Tetrahedron Lett 40:5391. (c) Alcaide B, Sáez E (2000) Tetrahedron Lett 41:1647

34. Brown D, Brown GA, Andrews M, Large JM, Urban D, Butts CP, Hales NJ, Gallagher T (2002) J Chem Soc Perkin Trans 1, 2014.

35. Ruano G, Grande M, Anaya J (2002) J Org Chem 67:8243.

36. Alcaide B, Almendros P, Rodríguez-Vicente A, Ruiz MP (2005) Tetrahedron 61:2767.

37. (a) Alcaide B, Almendros P, Aragoncillo C (2001) J Org Chem 66:1612; (b) Alcaide B, Almendros P, Aragoncillo C (1999) Chem Commun 1913.

38. Penfold DJ, Pike K, Genge A, Anson M, Kitteringham J, Kilburn JD (2000) Tetrahedron Lett 41:10347. 
39. Joshi SN, Puranik VG, Deshmukh ARAS, Bhawal BM (2001) Tetrahedron: Asymmetry 12:3073.

40. Alcaide B, Almendros P, Rodríguez-Acebes R (2005) Synthesis 2335.

41. (a) Alcaide B, Almendros P, Aragoncillo C (2003) Org Lett 5:3795; (b) Alcaide B, Almendros P, Aragoncillo C, Redondo MC (2007) J Org Chem 72:1604.

42. Alcaide B, Almendros P, Pardo C, Rodríguez-Vicente A, Ruiz MP (2005) Tetrahedron 61:7894.

43. (a) Barrett AGM, Baugh SPD, Braddock DC, Flack K, Gibson VC, Procopiou PA (1997) Chem Commun 1375; (b) Barrett AGM, Baugh SPD, Gibson VC, Giles MR, Marshall EL, Procopiou PA (1997) Chem Commun 155; (c) Barrett AGM, Baugh SPD, Braddock DC, Flack K, Gibson VC, Giles MR, Marshall EL, Procopiou PA, White AJP, Willians DJ (1998) J Org Chem 63:7893.

44. Barrett AGM, Ahmed M, Baker SP, Baugh SPD, Braddock DC, Procopiou PA, White AJP, Willians DJ (2000) J Org Chem 65:3716.

45. Tarling CA, Holmes AB, Markwell RE, Pearson ND (1999) J Chem Soc Perkin Trans 1, 1695.

46. (a) Alcaide B, Almendros P, Alonso JM, Redondo MC (2003) J Org Chem 68:1426; (b) Alcaide B, Almendros P, Alonso JM, Aly MF, Redondo MC (2001) Synlett 773.

47. Burwood M, Davies B, Díaz I, Grigg R, Molina P, Sridharan V, Hughes M (1995) Tetrahedron Lett 36:9053.

48. $\quad$ Alcaide B, Almendros P, Rodríguez-Acebes R (2005) J Org Chem 70:2713.

49. Alcaide B, Almendros P, Aragoncillo C (2002) Chem Eur J 8:1719.

50. Alcaide B, Almendros P, Martínez del Campo T (2007) Angew Chem Int Ed 46:6684.

51. Alcaide B, Almendros P, Martínez del Campo T, Soriano E, Marco-Contelles, JL (2009) Chem Eur J 15:1901.

52. Alcaide B, Almendros P, Martínez del Campo T, Soriano E, Marco-Contelles, JL (2009) Chem Eur J 15:1909.

53. Pal R, Basak A (2006) Chem. Commun 2992.

54. He M, Bode JW. (2008) J Am Chem Soc 130:418.

55. Alcaide B, Almendros P, Luna A, Martínez del Campo T (2008) J Org Chem 73:1635.

56. Garud DR, Koketsu M (2008) Org Lett 10:3319.

Autores: Alcaide, B.; Almendros, P.

Título: Novel Aspects on the Preparation of Spirocyclic and Fused Unusual $\beta$-Lactams, chp. 1, pp 1-48

Libro: Topics in Heterocyclic Chemistry Vol. 22, edited by R. R. Gupta and B. K. Banik, SPRINGER-VERLAG: Berlín-Heidelberg, 2010. 